\title{
Does bank capitalization matter for bank stock returns?
}

\author{
Qiubin Huang, Jakob de Haan, and Bert Scholtens
}

\begin{tabular}{|c|c|}
\hline Date of deposit & 25022020 \\
\hline Document version & Author's accepted manuscript \\
\hline Access rights & $\begin{array}{l}\text { Copyright (c) } 2020 \text { Elsevier Inc. All rights reserved. This work is } \\
\text { made available online in accordance with the publisher's policies. } \\
\text { This is the author created, accepted version manuscript following } \\
\text { peer review and may differ slightly from the final published } \\
\text { version. }\end{array}$ \\
\hline $\begin{array}{l}\text { Citation for } \\
\text { published version }\end{array}$ & $\begin{array}{l}\text { Huang, Q., de Haan, J., \& Scholtens, B. (2020). Does bank } \\
\text { capitalization matter for bank stock returns? North American } \\
\text { Journal of Economics and Finance, 52, [101171]. }\end{array}$ \\
\hline $\begin{array}{l}\text { Link to published } \\
\text { version }\end{array}$ & https://doi.org/10.1016/j.najef.2020.101171 \\
\hline
\end{tabular}

Full metadata for this item is available in St Andrews Research Repository at: https://research-repository.st-andrews.ac.uk/

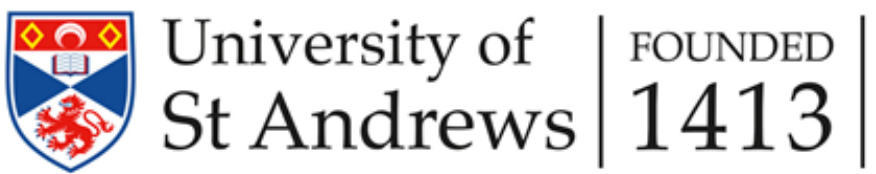




\title{
Does bank capitalization matter for bank stock returns?
}

\begin{abstract}
We examine US bank capitalization and its association with bank stock returns, and find that the book- and market-based capital ratios show a different pattern of US bank capitalization in the past thirty years. Our Fama-MacBeth regressions and portfolio analyses suggest that banks' market-based capital ratios are negatively associated with banks' stock returns during the (tranquil) 1994-2007 period while book-based capital ratios are positively associated with banks' stock returns during the (turbulent) 2008-2014 period. These results suggest that the effect of bank capitalization on bank stock returns depends on the capital measure used and the period considered.
\end{abstract}

Keywords: Bank capitalization · Bank stock returns · Portfolio analysis · Fama-MacBeth regression

JEL codes: G12, G21, G28 


\section{Introduction}

Bank capital plays a critical role in absorbing bank insolvency risk and promoting financial stability. For this reason, the Basel Committee on Bank Supervision came up with stricter capital requirements for banks to cope with individual and systemic financial risk. ${ }^{1}$ While stricter capital requirements are generally believed to make banks safer (Adrian et al., 2015; Dermine, 2015), ${ }^{2}$ little is known about the evolution of bank capitalization and its effect on bank stock returns. A few studies have shown that banks' capital ratios were well above the regulatory minimum and that there was also substantial variation (see Flannery and Rangan, 2008; and Gropp and Heider, 2010), but we are not aware of any comprehensive investigation on the evolution of US bank capitalization and its association with bank stock returns.

This leads to our first two questions: 1) how does US bank capitalization evolve since Basel I, and 2) are larger banks less capitalized as suggested by Gandhi and Lustig (2015)? Our third question is whether the variation in bank capitalization is cross-sectionally associated with the variation in expected bank stock returns. Finally, we examine whether the association between bank capitalization and returns differs between tranquil and turbulent periods, as suggested by the nonlinear risk-return trade-off due to investors' flight-to-quality in turbulent periods (e.g., see Ghysels et al., 2014, 2016; and Kotchoni, 2018). ${ }^{3}$ Insights about these four issues may have important implications for financial regulation, financial stability and asset pricing in the stock market.

To answer these questions, we first collect data for a large sample of publicly traded commercial banks in the US during the 1985-2014 period, containing 519 banks on average per year. We employ three proxies for bank capitalization: the book-valued capital ratio (BCR), the market-valued capital ratio (MCR), and the stressed capital ratio (SCR). The BCR is calculated as the book equity-to-asset ratio while the MCR is the ratio of market equity to the sum of market equity and book debt, as used in Flannery and Rangan (2008). Because book values are inherently backward-looking while market values are forward-looking, the BCR and

\footnotetext{
${ }^{1}$ For the development of the Basel Accords, see https://www.bis.org/bcbs/history.htm.

${ }^{2}$ Stricter capital requirements may also have other consequences. For instance, Noss and Toffano (2016) find that an increase in bank capital requirements reduces bank lending during an economic upswing. Van den Heuvel (2008) reports that higher capital requirements reduce banks' liquidity creation and increase welfare cost, while Baker and Wurgler (2015) conclude that stricter capital requirements raise the cost of bank capital.

${ }^{3}$ Based on the S\&P500 index, Ghysels et al. (2014) find that there are regime switches in the risk-return trade-off in the US stock market. The risk-return relation is negative in the first regime characterized by low ex post returns and high volatility, and positive in the second regime. They interpret the first regime as a flight-toquality regime. Similarly, Ghysels et al. (2016) find that the Merton model only holds during periods without financial crises and attribute this result to investors' flight-to-quality during turbulent periods. Using a different approach, Kotchoni (2018) also detects a nonlinear risk-return trade-off on the S\&P500 index.
} 
the MCR may provide different insights into bank capitalization. Furthermore, the reliability of book information may be questioned as bank balance sheets are notoriously opaque and easy to manipulate (e.g., see Lesle and Avramova, 2012; Mariathasan and Merrouche, 2014; Acharya et al., 2014; and Schuermann, 2014). The MCR may provide a more reliable assessment of bank capitalization than the BCR as bank managers usually have no incentives to manipulate market data.

In addition to these two unconditional measures, we introduce the SCR to capture bank capitalization under stress. The SCR is derived from the conditional capital shortfall approach of Brownlees and Engle (2017) and estimated as the expected MCR conditional on a severe market decline. The Global Financial Crisis (GFC) has highlighted the need for regulators to take systemic risk into account (Hanson et al., 2011; and Webber and Willison, 2011) and motivated the Federal Reserve to conduct annual macro-prudential stress tests. Similar to these macro-prudential stress tests, the SCR aims to assess bank capitalization under stress. We adopt the SCR in our analysis instead of the regulatory stressed capital ratio because the latter is only available after the GFC so that we have not enough data to study its asset pricing implications. Acharya et al. (2014) find that the SCR is strongly correlated with the stressed Tier 1 leverage ratio as used in the recent US and European macro-prudential stress tests. Thus, our analysis based on the SCR may lend some insights to the potential asset pricing implications of the regulatory stress tests.

We calculate monthly BCR, MCR and SCR for all banks in our sample and take the value-weighted average $\mathrm{BCR}, \mathrm{MCR}$ and SCR across banks to observe the overall evolution of bank capitalization. The value-weighted average BCR indicates that bank capitalization rose almost steadily in the past three decades, while the value-weighted average MCR and SCR reveal substantial changes in bank capitalization over time which were associated with banking crises and new regulations for the banking sector. Our results for the BCR and the MCR (SCR) suggest that US bank capitalization increased in the 1990s, as found by Flannery and Rangan (2008). However, the value-weighted average MCR (SCR) tended to decrease in the 2000s while the value-weighted average BCR kept increasing throughout the sample period. This different direction of the evolution of US bank capitalization in 2000s is not reported in Flannery and Rangan (2008). Furthermore, we find that whether larger banks are better capitalized depends on the capital measure used and the period examined. These results point to different directions of the evolution of bank capitalization and highlight the need to assess bank capitalization from different perspectives.

After investigating the evolution of bank capitalization, we proceed to examine the role of bank capitalization in the cross section of bank stock returns. To this end, we resort to a 
statistical approach widely used in empirical asset pricing research, i.e., investigating the crosssectional relationship between bank capitalization and bank stock returns based on a sorting methodology (e.g., see Fama and French, 1993; Vassalou and Xing, 2004; Campbell et al., 2008; Gandhi and Lustig, 2015; and Bouwman et al., 2018). We sort banks into decile portfolios based on their monthly BCRs and calculate one-month-ahead average returns for each of the BCR-sorted decile portfolios. We repeat the same procedure to construct the MCR- and SCRsorted decile portfolios. If banks with lower capital ratios are associated with higher insolvency risk, ${ }^{4}$ then the first decile portfolio would consist of the most fragile banks while the tenth decile portfolio would consist of the soundest banks. According to the intuitive risk-return trade-off, we expect that lower-BCR (MCR or SCR) portfolios have higher expected returns in order to compensate investors for bearing higher insolvency risk.

We find a hump-shaped cross-sectional relationship between portfolio average BCR (MCR and SCR) and average excess returns for our full sample period (1985-2014), which is mainly due to the impact of the systemic banking crises. In the periods 1985-1993 and 2008-2014, in which there were many bank failures (see Figure 3), we find that the relationship tends to be positive. The different relationship in crisis periods is probably due to market fear or great uncertainty which could cause investors to change their beliefs frequently and dramatically (Hoffmann et al., 2013; and Gennaioli et al., 2015). ${ }^{5}$ During turbulent periods, investors are argued to be uncertainty-averse and prefer to hold safe assets (see Ozoguz, 2009; Caballero and Krishnamurthy, 2008; Guerrieri and Shimer, 2014; and Adrian et al., 2017). Stock prices of riskier banks could continuously decrease during and even after a banking crisis due to the illiquidity of riskier stocks (Anand et al., 2013) and investors' under-reaction to good news (Veronesi, 1999). Under such circumstances, the intuitive risk-return trade-off would no longer hold. In fact, several recent studies have found a negative risk-return relation in the US stock market during turbulent periods (see the papers cited in Footnote 3). These studies highlight the need to distinguish between tranquil and turbulent periods when examining the role of bank capitalization in the cross-section of bank stock returns.

Therefore, we divide the full sample period to a tranquil period (1994-2007) and two turbulent periods (1985-1993 and 2008-2014) according to the frequency of bank failure. On average, only five banks failed per year during the tranquil period while 240 banks failed per year during 1985-1993 and 72 per year during 2008-2014. During the tranquil period, we find that

\footnotetext{
${ }^{4}$ Theoretically, Diamond and Rajan (2000) demonstrate a negative relationship between a bank's capital and its probability of financial distress. Empirically, Berger and Bouwman (2013) find that bank capital has a positive impact on the probability of bank survival.

${ }^{5}$ Similarly, Campbell et al. (2008) find that firms with higher probability of financial distress have unusually lower stock returns which they attribute to behavioral factors. See also Fiegenbaum and Thomas (1988), Campbell and Viceira (2005) and Wang et al. (2017).
} 
portfolio excess returns ${ }^{6}$ nearly monotonically decrease with the increase of bank capitalization. This negative relationship is particularly evident when bank capitalization is captured by the MCR or the SCR. In contrast, portfolio excess returns tend to increase with the increase of bank capitalization during the turbulent period. This positive relationship is particularly evident during 2008-2014 when bank capitalization is captured by the BCR. These findings are further confirmed by our Fama-MacBeth cross-sectional regressions of individual bank stock returns on the capital ratios controlling for banks' market beta, size and book-to-market ratio.

To further understand the role of bank capitalization in the cross section of bank stock returns, we proceed to examine whether the patterns in portfolio excess returns are due to bank capitalization per se, or driven by the cross-sectional variation in portfolio exposures to systematic risk factors. To this end, we apply the five-factor model of Fama and French (2015) to estimate the risk-adjusted returns of our decile portfolios and their exposures to systematic risk factors. ${ }^{7}$ We also examine the five-factor model augmented by Gandhi and Lustig's (2015) bank-specific size factor and by another two bond risk factors, and find that the results based on the five-factor model are robust.

We first focus on the tranquil period. After risk adjustment, the variation in risk-adjusted returns of the BCR-sorted portfolios is no longer significant. The portfolios have significant and decreasing loadings on the market and value factors. These results suggest that the BCR proxies for sensitivities to the market and value factors, which results in variation in portfolio excess returns. In contrast, the risk-adjusted returns of the MCR-sorted (SCR-sorted) portfolios are still significantly associated with portfolio average MCR (SCR). After risk adjustment, the longshort zero-cost portfolio that goes long in the first decile MCR-sorted (SCR-sorted) portfolio and short in the tenth decile MCR-sorted (SCR-sorted) portfolio still earns average returns of $0.85 \%$ $(0.78 \%)$ per month, which are economically sizable and statistically significant. Besides, both the MCR- and SCR-sorted portfolios have significant and decreasing loadings on the market and size factors, but not on other factors. The long-short portfolios also have significant loadings on the market and size factors, but not on other factors. These results suggest that the differences in exposures to the market factor and in exposures to the size factors contribute to the crosssectional variation in portfolio returns, but they are not the main reasons. Bank capitalization captured by the MCR or the SCR is the main driver for the cross-sectional variation in portfolio returns.

\footnotetext{
${ }^{6}$ To be clear, in this paper we refer to excess return as raw return minus the risk-free rate; and risk-adjusted return as the intercept (also called alpha) of Fama-French factor models.

${ }^{7}$ Although not reported, we also tested other models, including the one-factor market model based on the Capital Asset Pricing Model (CAPM), the three-factor model of Fama and French (1993) and the four-factor model of Carhart (1997), and find that they do not outperform the five-factor model in explaining the variation in returns of the bank stock portfolios.
} 
For the turbulent period 2008-2014, ${ }^{8}$ we find significant variation in risk-adjusted returns of the BCR-sorted (but not the MCR- or SCR-sorted) decile portfolios. The results suggest that only the BCR is positively associated with bank stock returns. ${ }^{9}$ This positive association violates the intuitive risk-return trade-off, but is supported by recent studies which suggest that investors flight to high-quality assets during crisis periods, leading to a negative riskreturn relation (e.g., see Ghysels et al., 2014; Guerrieri and Shimer, 2014; Adrian et al., 2017; and Kotchoni, 2018). We do not find a significant association of the MCR and the SCR with bank stock returns during the turbulent period. A possible reason is that investors pay more attention to the accounting assessment (the BCR) of bank capitalization rather than the market assessment during the turbulent period.

Our research contributes to the following literature. First, several studies have examined the determinants of bank capital structure (Gropp and Heider, 2010) and of the build-up of bank capital (Flannery and Rangan, 2008). Both studies find that bank capital ratios are maintained well above the regulatory minimum. Miles et al. (2013) estimate the costs and benefits of banks holding more capital and find that the desirable amount of capital is much larger than banks have used in recent years and than targets agreed upon in the Basel III framework. Brewer III et al. (2008) examine why bank capital ratios vary across countries while Goddard et al. (2016) explore the reasons for bank capital ratios varying over time. We contribute to these studies by showing the different evolutions of bank capitalization captured by different measures, highlighting the need for future research to assess bank capital from different perspectives.

Second, several recent studies have examined the effect of bank capital on different variables, such as bank survival and market share (Berger and Bouwman, 2013), stock prices (Akhigbe et al., 2012), stock returns (Demirgüç-Kunt et al., 2013; Pelster et al., 2018; and Bouwman et al., 2018), and bank lending (Carlson et al., 2013). These studies find significant effects of bank capital mainly during financial crises. Our research contributes to these studies by showing that bank capitalization has a different impact on bank stock returns during tranquil and turbulent periods. The work most closely related to our research is Bouwman et al. (2018) who examine the effect of bank capital on bank stock returns during bad times and other times. The main difference between the study of Bouwman et al. (2018) and ours is the way to distinguish between different economic times, which results in somewhat different findings. Bouwman et al. (2018)

\footnotetext{
${ }^{8}$ As there may be a substantial sample selection bias prior to 1994 due to the significant increase of COMPUSTAT's coverage of banks from 1989 to 1993 (Bouwman et al., 2018), our analysis for the turbulent period focuses on the 2008-2014 period.

9 This finding is similar to the results of Bouwman et al. (2018) who show that banks with higher BCRs have higher risk-adjusted stock returns only in bad times, where bad times are defined as those months when value-weighted bank stock return volatility exceeds its 80th percentile during 1994-2015.
} 
define bad times as those months when value-weighted bank stock return volatility exceeds its 80th percentile during 1994-2015 and find that high-capital banks have higher risk-adjusted stock returns only in bad times. In contrast, we distinguish between tranquil and turbulent periods according to the frequency of bank failures where, on average, the tranquil period (19942007) and the turbulent period (2008-2014) contain 5 and 72 bank failures per year, respectively. We find that banks with higher BCRs have higher risk-adjusted stock returns only during the turbulent period while banks with higher MCRs have lower risk-adjusted stock returns only during the tranquil period. In this respect, our research also contributes to understanding the time-varying and measure-dependent impact of bank capital on bank stock returns. Related studies are Bessler and Kurmann (2014) and Bessler et al. (2015) who uncover time-varying systematic and idiosyncratic risk exposures of US banks.

The remainder of the paper is structured as follows. Section 2 describes the three measures of bank capitalization and our bank sample, and investigates the evolution of US bank capitalization captured by different measures. Section 3 explores the cross-sectional relationship between bank capitalization and bank stock returns. Section 4 examines the risk-adjusted returns of portfolios sorted on bank capital ratios. Section 5 reports several robustness checks. Section 6 concludes.

\section{US bank capitalization during 1985-2014}

We introduce three measures of bank capitalization in Section 2.1 and present our bank sample in Section 2.2. In Section 2.3, we study the evolution of US bank capitalization captured by different measures.

\subsection{Bank capital ratios}

A bank's capital ratio is usually measured as the ratio of equity to assets. We consider three measures of the capital ratio: the book-valued capital ratio (BCR), the market-valued capital ratio (MCR) and the stressed capital ratio (SCR). The BCR is calculated as the book equityto-asset ratio while the MCR is the ratio of market equity to the sum of market equity and book debt. Flannery and Rangan (2008) also use the BCR and MCR measures to investigate US bank capitalization with a focus on the MCR measure. The SCR of a bank is estimated as the bank's expected MCR conditional on a severe market decline, i.e., the stock market index drops by $10 \%$ in a month, as suggested by Brownlees and Engle (2017). 
We consider the BCR and the MCR for the reason that supervisors typically assess banks' capital adequacy based on equity's book value, while markets price claims using market values. Banks therefore have to satisfy not only regulatory but also market constraints on their equity (Flannery and Rangan, 2008). Because book values are inherently backward-looking while market values are typically forward-looking, a bank's BCR and MCR are not perfectly correlated and may provide different insights into bank capitalization. Furthermore, the reliability of book information may be questioned as bank balance sheets are notoriously opaque and easy to manipulate (e.g., see Lesle and Avramova, 2012; Mariathasan and Merrouche, 2014; Acharya et al., 2014; and Schuermann, 2014). The MCR may provide a more objective assessment of bank capitalization than the BCR as bank managers usually have limited means to manipulate market data.

We also consider the SCR motivated by recent financial regulatory reforms. Prudential regulation had focused on risk assessment at the level of individual banks' balance sheets before the GFC, but the crisis clearly highlighted the need for regulation to take systemic risk into account (Hanson et al., 2011; and Webber and Willison, 2011). Regulation based on individual banks' capital requirements is inadequate for the sake of financial stability (Schuermann, 2014). The GFC has pointed out the need for macro-prudential regulation to safeguard the stability of the financial system as a whole (Hanson et al., 2011). As a result, some supervisory agencies (e.g., the Federal Reserve) started to use macro-prudential stress tests to assess whether banks have enough capital to absorb losses during stressful conditions. ${ }^{10}$ Similar to these macroprudential stress tests, the SCR aims to assess bank capitalization under stress. Acharya et al. (2014) find that the SCR is strongly correlated with the stressed Tier 1 leverage ratio as used in the recent US and European macro-prudential stress tests. The SCR is derived from the SRISK approach of Brownlees and Engle (2017), capturing individual banks' market-valued capital levels given that the market is in distress. The derivation and estimation of the SCR are shown in Appendix A. We do not use the supervisory stressed capital ratio because there is not enough data for our study. ${ }^{11}$ The outcomes of the supervisory stress tests conducted by the Federal Reserve are only available for a small sample of large banks in recent years. In contrast, the estimation of the SCR relies on publicly available market data and can be obtained throughout our sample period. This enables us to compare the evolution of banks' SCRs with BCRs and MCRs over a long period.

\footnotetext{
10 The Federal Reserve conducts annual supervisory stress tests for banks with $\$ 50$ billion or more in total consolidated assets since 2013 pursuant to the Dodd-Frank Act. For information about techniques and results of the Dodd-Frank Act Stress Testing, see www.federalreserve.gov/supervisionreg/dfa-stress-tests.htm.

11 Another reason that we do not examine regulatory capital ratios is because they may have become too complex to verify and too error-prone to be reliably robust, as argued by Herring (2018).
} 


\subsection{Bank sample and descriptive statistics}

Our research focuses on US listed commercial banks during the 1985-2014 period. We obtain daily stock returns of banks from the Center for Research in Security Prices (CRSP) Daily Stock File and daily returns on the CRSP value-weighted market portfolio as a proxy for stock market returns. We also collect monthly data on bank shares outstanding, equity prices and returns, and data on market returns from the CRSP Monthly Stock File. We gather information on book values of banks' assets, liabilities and equity from COMPUSTAT. These data are used to calculate capital ratios for banks and to explore the relationship between bank capitalization and stock returns. To identify banks in the CRSP database, we define US commercial banks as those firms with Standard Industrial Classification (SIC) codes beginning with 60 or historical SIC code 6712, following Gandhi and Lustig (2015). We exclude banks for which we have less than two years of stock return data in order to have enough observations to estimate banks' stressed capital ratios. At this stage, there are 1,694 banks in our sample.

Figure 1 shows the average number of banks in each year. The average number of listed banks in our sample increased quickly after 1985 and reached a peak with 758 banks in 1999, after which it decreased to 410 in 2014. Although capital ratios can be constructed for some banks for as early as 1965, our analyses focus on banks between 1985 and 2014 as there are too few publicly listed commercial banks for sorting purposes prior to 1985. Furthermore, data on the book value of commercial banks are not available for a substantial number of banks in COMPUSTAT prior to 1980s. Bouwman et al. (2018) also point out that there may be substantial sample selection bias prior 1994 due to the significantly increase of the COMPUSTAT coverage of banks from 1989 to 1993 . We bear this concern in mind throughout our analyses. Still, our sample period covers three decades and more than three business cycles as identified by the National Bureau of Economic Research. ${ }^{12}$ On average, there are 519 banks per year during 1985-2014, which enables us to explore the asset pricing implications of bank capital by sorting banks into multiple portfolios.

Table 1 gives descriptive statistics for the main variables for the 1985-2014 period. In order to reduce the effect of outliers, values above the 99th percentile are set to the value of the 99th percentile. The process of trimming data may affect the basic statistics like mean, standard deviation, minimum and maximum. Therefore, we also present the deciles of each variable in Table 1. The average monthly stock return across all banks in our sample during 1985-2014 is $0.86 \%$ with a standard deviation of $8.27 \%$. Banks' market equity value ranges from $\$ 0.01$ billion to $\$ 7.03$ billion and the book-to-market ratio (BM) ranges from 0.24 to 64.75 . The BCR has a mean of $9.18 \%$ and a standard deviation of $2.79 \%$. Both the mean and standard deviation of

\footnotetext{
${ }^{12}$ See www.nber.org/cycles.html for reference dates of US business cycles.
} 


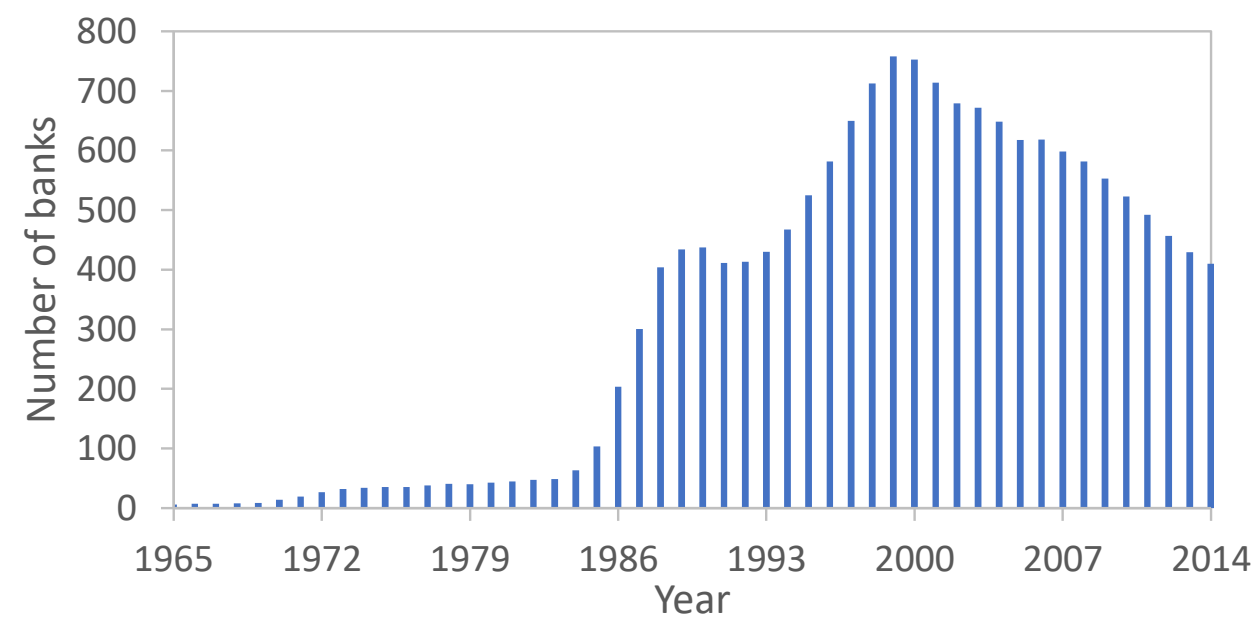

US listed commercial banks are recognized by firms with SIC codes beginning with 60 or historical SIC code 6712 following Gandhi and Lustig (2015). The number of banks in a year is calculated as the average number of banks in each month within the year.

Figure 1. Number of US listed banks in each year

the BCR are smaller than those of the MCR and the SCR. We find that $37.57 \%$ of bank-month observations in our sample fail to meet the prudential capital ratio of $8 \%$ according to the BCR, while it is $25.75 \%$ and $27.76 \%$ according to the MCR and the SCR, respectively. Besides, the mean of banks' SCR is about $0.5 \%$ lower than that of banks' MCR, reflecting the adjustment for systemic risk.

Table 1: Descriptive statistics of banks between 1985 and 2014

Return, ME, BM indicate stock returns (\%), market value of equity ( $\$$ billion), and book-to-market ratio of equity, respectively. BCR, MCR and SCR indicate book-valued capital ratio (\%), market-valued capital ratio (\%) and stressed capital ratio (\%), respectively. The descriptive statistics are computed based on 147,104 monthly observations for each variable for all US listed banks in our sample between 1985 and 2014 .

\begin{tabular}{|c|c|c|c|c|c|c|c|c|c|c|c|c|c|}
\hline & \multirow{2}{*}{ Mean } & \multirow{2}{*}{ Std. } & \multirow{2}{*}{ Min } & \multirow{2}{*}{$\operatorname{Max}$} & \multicolumn{9}{|c|}{ Decile } \\
\hline & & & & & 1 & 2 & 3 & 4 & 5 & 6 & 7 & 8 & 9 \\
\hline Return & 0.86 & 8.27 & -50.53 & 55.69 & -8.00 & -4.52 & -2.38 & -0.72 & 0.66 & 2.13 & 3.99 & 6.46 & 10.39 \\
\hline $\mathrm{ME}$ & 0.58 & 1.10 & 0.01 & 7.03 & 0.02 & 0.04 & 0.06 & 0.09 & 0.13 & 0.21 & 0.35 & 0.68 & 1.72 \\
\hline $\mathrm{BM}$ & 1.10 & 1.86 & 0.24 & 64.75 & 0.43 & 0.52 & 0.60 & 0.68 & 0.77 & 0.88 & 1.01 & 1.20 & 1.60 \\
\hline BCR & 9.18 & 2.79 & 2.44 & 17.71 & 5.95 & 6.83 & 7.54 & 8.14 & 8.74 & 9.38 & 10.15 & 11.24 & 13.19 \\
\hline MCR & 12.00 & 5.68 & 0.09 & 29.87 & 4.85 & 6.97 & 8.71 & 10.26 & 11.70 & 13.21 & 14.84 & 16.88 & 19.72 \\
\hline SCR & 11.52 & 5.49 & 0.08 & 29.50 & 4.64 & 6.67 & 8.37 & 9.83 & 11.21 & 12.61 & 14.22 & 16.21 & 18.97 \\
\hline
\end{tabular}

To further understand the similarities and differences between banks' BCRs, MCRs and SCRs, we calculate their pairwise cross-sectional correlations in each month. Figure 2 shows the 12-month backward moving averages of the correlations. The correlation between banks' BCRs 
and MCRs (SCRs) ranges from 0.4 to 0.8 during 1985-2014, with a mean of $0.6(0.6) .{ }^{13}$ This relatively low correlation suggests that the market valuation of bank capital is different from that based on banks' balance sheets. The cross-sectional correlation between banks' MCRs and SCRs is above 0.97 for all months, suggesting that the MCR and the SCR capture quite similar features of banks.

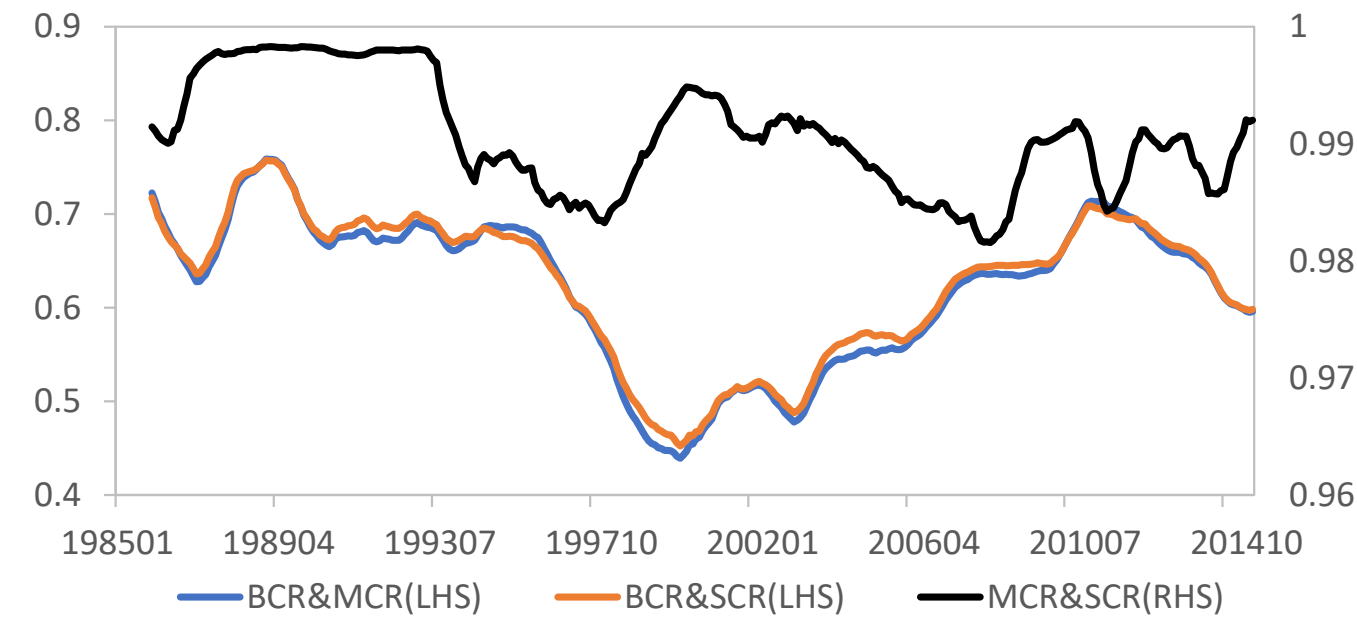

This figure displays 12-month backward moving averages of cross-sectional correlations between banks' BCRs, MCRs and SCRs. BCR\&MCR, BCR\&SCR and MCR\&SCR denote correlations between SCR and MCR, between SCR and BCR, between BCR and MCR, respectively.

Figure 2. Monthly cross-sectional correlations between banks' BCRs, MCRs and SCRs

\subsection{Evolution of bank capitalization}

Here we examine the evolution of bank capitalization in the last three decades and compare the results of different capital ratios. We calculate the value-weighted average BCR, MCR and SCR across banks and present the results in Figure 3 for our sample of 1,694 banks during the 1985-2014 period. In Figure 3, we also plot the number of bank failures in each month (grayshaded regions) and the NBER recessions (light-shaded regions), as well as the enactments of the Financial Institutions Reform Recovery and Enforcement Act (FIRREA) in August 1989, the Federal Deposit Insurance Corporation Improvement Act (FDICIA) in December 1991, the Gramm-Leach-Bliley Act (GLBA) in November 1999 and the Dodd-Frank Act (DFA) in July 2010 .

We find that the average BCR across banks increased from 5.53\% in January 1985 to $10.72 \%$ in December 2014, with a standard deviation of $1.47 \%$. Even during the GFC, the

\footnotetext{
${ }^{13}$ This finding is similar to the result of Flannery and Rangan (2008) who calculate cross-sectional correlations between banks' BCRs and MCRs based on the largest 100 banks during 1986-2001.
} 


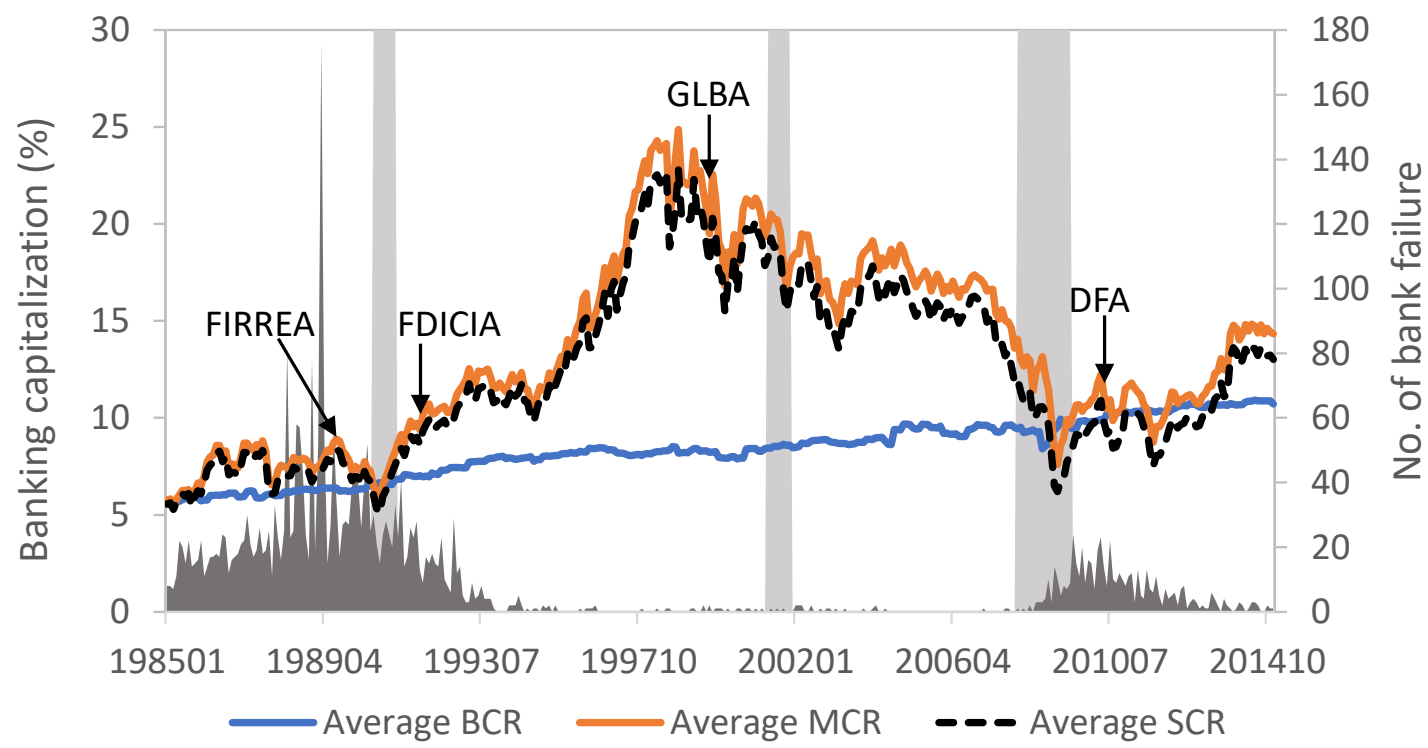

Average BCR (MCR or SCR) indicates the value-weighted average book-value (market-value or stressed) capital ratio across all banks in our sample. The gray-shaded regions indicate the number of bank failures in each month. A bank failure is the closing of a bank by a federal or state banking regulatory agency because the bank is unable to meet its obligations to depositors and others. The number of bank failures is obtained from www5.fdic.gov/ hsob/SelectRpt.asp?EntryTyp=30\&Header=1. The light-shaded regions represent NBER recessions where the recession dates are published by the NBER Business Cycle Dating Committee. FIRREA, FDICIA, GLBA and DFA are short for the enactment of the Financial Institutions Reform Recovery and Enforcement Act in August 1989, the Federal Deposit Insurance Corporation Improvement Act in December 1991, the Gramm-Leach-Bliley Act in November 1999 and the Dodd-Frank Act in July 2010, respectively.

Figure 3. Bank capitalization during 1985-2014

average BCR remained above $8.4 \%$, i.e. higher than the prudential capital ratio of $8 \%$ (see Figure 3). According to the average BCR, it seems that the US banking capitalization was rising most of the time, thereby hardly providing useful signals for the occurrence of financial distress.

In contrast, both the average MCR and SCR across banks had substantial variation during our sample period and were closely associated with the changes of financial regulation and stability. For example, the average MCR had a mean of $13.48 \%$ over the period of 1985-2014, with a standard deviation of $4.78 \%$. The results of the average MCR (SCR) suggest that bank capital ratios (under stress) were less than $8.5 \%$ during the Saving and Loan crisis in the second half of the 1980s. With the enactment of the FIRREA in August 1989 to resolve insolvent banks, there were 327, 213 and 144 thrifts closed or resolved in 1989, 1990 and 1991, respectively (Curry and Shibut, 2000). In this period, banks' average MCR fell from 8.37\% in August 1989 to $5.09 \%$ in October 1990, indicating a less well-capitalized banking sector. With the decreasing thrift failures and the enactment of the FDICIA in December 1991, banks' average MCR started to increase from November 1990 and peaked at $22.7 \%$ in November 1998. While 
the under-capitalization of banks in 1980s could be attributed to the financial deregulation in the early 1980s (Dotsey and Kuprianov, 1990), the build-up of bank capital in 1990s was mainly due to the regulatory innovations in the early 1990s (Flannery and Rangan, 2008). Flannery and Rangan demonstrate that the FDICIA weakened market participants' expectations on government bailouts for failed bank and forced banks to align their capital ratios more in line with their risk exposure.

During the Long-Term Capital Management (LTCM) crisis, both the average MCR and SCR were at their highest around $21 \%$ in our sample period, indicating strong abilities of banks to withstand shocks. Although a subset of banks lost $29 \%$ of their equity capitalization in six trading days during the LTCM crisis, this had little impact on other banks (Kho et al., 2000). However, banks' average MCR and average SCR began to decrease after the LTCM crisis and this trend lasted for almost ten years until the GFC. In contrast to banks' average BCR that kept increasing during this period, the decreasing average MCR (SCR) indicated the rising vulnerabilities of the US banking which finally turned into the 2007-2009 financial crisis (see Merrouche and Nier, 2010).

This long period of sustained decrease in average MCR (SCR) was probably due to financial liberalization and deregulation led by the GLBA, and market participants' overconfidence. The GLBA allowed investment banks, commercial banks, securities firms and insurance companies to operate as a conglomerate, but it failed to give any financial regulatory agency the authority to regulate large investment bank holding companies. Banks experienced a significant increase in risk after the enactment of the GLBA (Akhigbe and Whyte, 2004). However, market participants overestimated bankers' risk-management skills and banks' abilities to withstand shocks due to the facts that banks survived during the LTCM crisis and the dot-com crash, and enjoyed a long period of sustained profitability and growth (Thakor, 2015b). ${ }^{14}$ Banks were encouraged to take more risks and operate with less capital while investors required unrealistically low risk premia (Thakor, 2015a).

The relatively low bank capitalization (captured by the MCR and SCR) did not help banks to withstand the shock of the subprime mortgage crisis, leading to a systemic banking crisis and an economic recession. Banks' average MCR (SCR) started to decrease sharply since November 2006, nine months prior to the start (August 2007) of the 2007-2009 financial crisis, and reached its bottom at $7.6 \%(6.2 \%)$ in February 2009, almost the end of the crisis (see

\footnotetext{
${ }^{14}$ Similarly, Demyanyk and Van Hemert (2009) find that securitizers were to some extent aware of the deteriorated quality of loans since 2001, but they tended to ignore the risk due to the high house price appreciation between 2003 and 2005. Kho et al. (2000) study the LTCM crisis and argue that systemic risk was over-rated and the cleverness of policymakers was underrated.
} 
Figure 3). Thanks to the rescue plans for insolvent banks (see, e.g., Acharya et al., 2009) and the following stricter regulations (especially the enactment of the Dodd-Frank Act), banking stability gradually improved, as illustrated by the gradually increasing average MCR (SCR) of banks between 2009 and 2014 .

Overall, the above analysis implies that banks' market-valued capital ratios are able to convey information about banks' riskiness, unlike banks' book-valued capital ratios. Banks' average MCR and average SCR clearly decreased (increased) when the number of bank failures increased (decreased), while banks' average BCR hardly changed (see Figure 3). Moreover, banks' average MCR (SCR) started to decrease before each of the economic recessions and to increase before the end of each recession, suggesting that banks' average MCR (SCR) is a forward-looking indicator of economic growth. In contrast, banks' average BCR rose steadily in our sample period (see Figure 3), failing to signal the occurrence of financial crises or economic recessions.

The above analyses focus on the aggregate capital levels of all banks, but large banks may be better capitalized since they face stricter supervisory capital requirements. To examine this, we sort banks into decile portfolios based on their size in ascending order every month, and calculate value-weighted average capital ratios across banks in each of the decile portfolios. Figure 4 presents the results.

Panel A of Figure 4 displays the average BCR of each size-sorted decile portfolio. We find that most size-sorted portfolios' average BCRs kept rising all the time with small variation, especially for the tenth decile portfolio which consists of the largest banks. In contrast, for the first decile portfolio, which consists of the smallest banks, the average BCR went up in the 1990s and down in the 2000s, and then went up again after the GFC. Moreover, the average BCR for the first decile portfolio was larger during 1994-2005 than that for the tenth decile portfolio. We can see from Panel A of Figure 4 that the portfolios had similar levels of BCR roughly before 1995, but became more dispersed during 1995-2014. These results suggest that banks' capitalization does not always move in the same direction and that large banks are not always better capitalized than small banks according to their book-valued capital ratios.

Panel B of Figure 4 displays the average MCR of each size-sorted decile portfolio. It clearly shows that all portfolios' average MCRs evolved in similar direction over time, and lower decile portfolios tended to have lower average MCRs. The results suggest that the market assessment of bank capitalization changes over time, but market participants view smaller banks as less capitalized almost all the time, which is different from the finding based on the book-valued capital ratios. For the SCR measure, Panel C shows quite similar results as the MCR measure 
shown in Panel B, which is in line with the analyses based on Figures 2 and 3. In the next section, we examine whether banks' BCR, MCR, and SCR have different impacts on bank stock returns.
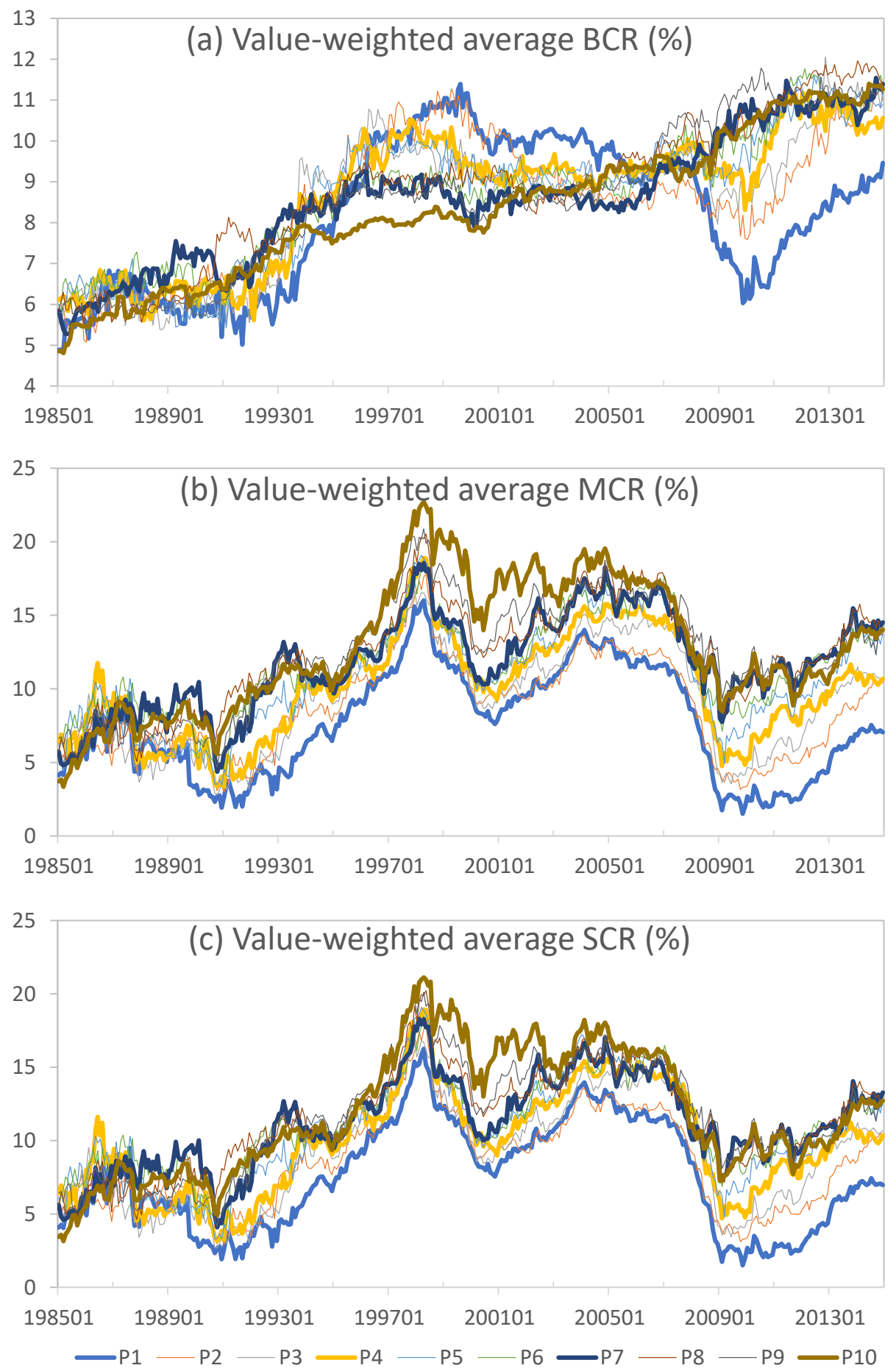

This figure shows (a) value-weighted average BCR, (b) value-weighted average MCR, and (c) value-weighted average SCR of each of the size-sorted decile portfolios (P1 - P10). The portfolios are reconstructed for each month. P1 indicates the first decile portfolio of the smallest banks while P10 indicates the tenth decile portfolio of the largest banks.

Figure 4. Average capital ratios of size-sorted decile portfolios 


\section{Capital ratios and the cross-section of bank stock returns}

This section examines the relationship between bank capitalization and expected stock returns, using the BCR, the MCR and the SCR as three proxies for bank capitalization. Section 3.1 sorts banks into decile portfolios based on each capital measure to give a first insight into the crosssectional relationship between bank capitalization and expected stock returns, and discusses the reason to distinguish between tranquil and turbulent periods. Section 3.2 performs Fama and MacBeth regression analysis to further establish the cross-sectional relationship controlling for other key variables. We show that the MCR and the SCR are negatively associated with bank stock returns only during the 1994-2007 period while the BCR is positively associated with bank stock returns only during the 2008-2014 period.

\subsection{Portfolio sorting analysis}

We begin our investigation of the cross-sectional relation between bank capitalization and expected stock returns with univariate-sorted portfolio analysis. Each month, we sort bank stocks in the sample into decile portfolios based on an ascending sorting of the BCR variable and calculate one-month-ahead equal-weighted returns of the BCR-sorted decile portfolios. ${ }^{15} \mathrm{We}$ repeat this procedure for MCR- and SCR-sorted decile portfolios.

Figure 5 plots the average returns (top panel) and the median returns (bottom panel) of the BCR-, MCR- and SCR-sorted decile portfolios in excess of the risk-free rate over our full sample period 1985-2014. We find that there is a somewhat hump-shaped relationship between bank capitalization and portfolio returns, especially when bank capitalization is captured by the MCR or the SCR. For example, the portfolio average return in excess of the risk-free rate increases from $0.45 \%$ for the first SCR-sorted decile portfolio to $0.9 \%$ for the third SCR-sorted decile portfolio, and then decreases to $0.37 \%$ for the tenth SCR-sorted decile portfolio (see the top panel of Figure 5). Outliers could be the cause of the hump-shaped relationship. Therefore, we also present the results when using median returns and still find a hump-shaped relationship (see the bottom panel of Figure 5). By construction, the first decile portfolio consists of the riskiest banks as indicated by their capital ratios while the tenth decile portfolio consists of the safest banks. ${ }^{16}$ The hump-shaped relation is therefore not in line with the intuition that

\footnotetext{
${ }^{15}$ Notice that portfolio returns can be calculated as equal-weighted or value-weighted average returns across banks in the portfolios. Although value-weighting accounts for the relative importance of banks in a portfolio, equal-weighting can avoid the impact of extremely large banks. Given that a large fraction of our sample banks is relatively small (see Table 1), we prefer to use equal-weighted average returns for our main analyses. In Section 5.5 , we employ value-weighted average returns as part of our sensitivity analysis.

${ }^{16}$ We expect that banks with higher capital ratios are more capable to withstand unexpected shocks because
} 
less capitalized banks are riskier and therefore have higher expected returns according to the risk-return trade-off principle.
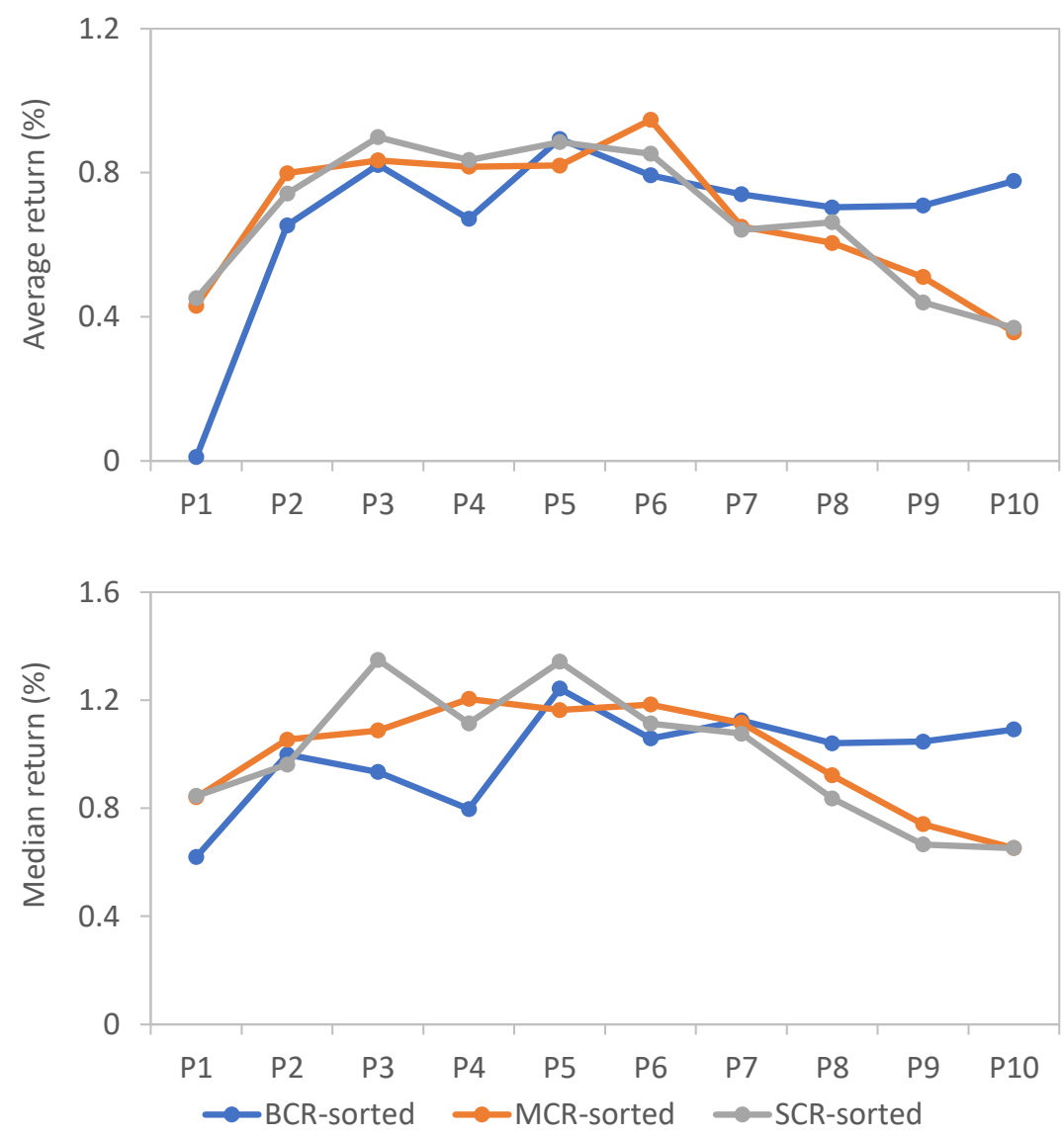

The horizontal axis shows the first to the tenth decile portfolio formed on the basis of banks' BCR, MCR or SCR. The vertical axis shows the portfolio average or median returns in excess of the risk-free rate during the January 1985 to December 2014 period, where a portfolio's monthly return is calculated as the equal-weighted one-month-ahead average return across banks in the portfolio minus the risk-free rate. Following Fama and French (1993), we take the US one-month Treasury bill rate as the risk-free rate.

Figure 5. Portfolio average and median excess returns: 1985-2014

The hump-shaped relation may be driven by the systemic banking crises in our sample period. ${ }^{17}$ Some studies have found that stock investors tend to overreact to unexpected and dramatic events, leading to a radical change in beliefs during financial crises (see De Bondt and Thaler, 1985; Chopra et al., 1992; Hoffmann et al., 2013; Gennaioli et al., 2012; and Gennaioli et al., 2015). During financial crisis periods, investors are argued to be uncertainty-averse and research has shown that well-capitalized banks have better performance in terms of earnings (Berger, 1995), survival probability (Allen et al., 2011), market value (Mehran and Thakor, 2011), market share and profitability (Berger and Bouwman, 2013).

17 Our full sample period contains two systemic banking crises with many bank failures, namely the Savings and Loan crisis in 1980s and early 1990s and the 2008-2009 financial crisis. The LTCM crisis in 1998 was not systemic according to Laeven and Valencia (2013). 
prefer to hold safe assets (see Ozoguz, 2009; Caballero and Krishnamurthy, 2008; Guerrieri and Shimer, 2014; and Adrian et al., 2017). Stock prices of riskier banks could continuously decrease during and even after a banking crisis due to the illiquidity of riskier stocks (Anand et al., 2013) and investors' under-reaction to good news (Veronesi, 1999). Under such circumstances, the risk-return trade-off would no longer hold. In fact, Bessler and Kurmann (2014) have found that banks' risk exposures significantly changed during the recent financial crisis. ${ }^{18}$ More generally, Ghysels et al. (2014) find strong evidence for regime changes in the risk-return trade-off on the S\&P500 index. Similarly, Ghysels et al. (2016) find that the Merton model only holds during periods excluding financial crises and attribute this to investors' flight-to-quality during turbulent periods. Using a different approach, Kotchoni (2018) also detects a nonlinear riskreturn trade-off on the S\&P500 index. Overall, these studies highlight the need to distinguish between turbulent and tranquil periods when examining the role of bank capital in the crosssection of bank stock returns.

Therefore, we divide the full sample period to a tranquil period (1994-2007) and two turbulent periods (1985-1993 and 2008-2014) according to the frequency of bank failure, and examine whether bank capitalization has a different impact on bank stock returns during the tranquil and turbulent periods. ${ }^{19}$ On average, only 5 banks failed per year during the tranquil period while 240 banks failed per year during 1985-1993 and 72 per year during 2008-2014 (see Figure 3). Although the 2008 financial crisis started in the third quarter of 2007, there were only three bank failures in 2007 and it became systemic in 2008 (Laeven and Valencia, 2013). This is the reason why we select December 2007 as the end month of the tranquil period. ${ }^{20}$ The reason for taking the post-crisis period $2010-2014$ as turbulent is that there were still many bank failures during this period (see Figure 3). There was also a stock market crash in May 2010 which was a systemic crisis according to Billio et al. (2012) as well as a sovereign debt crisis in Europe. Although we try to carefully define the tranquil and turbulent periods, we discuss our empirical findings using alternative definitions of the tranquil and turbulent periods

\footnotetext{
18 Another strand of literature finds that bank capital has a significant impact only during financial crises on bank lending (Carlson et al., 2013), bank stock returns (Demirgüç-Kunt et al., 2013; and Bouwman et al. 2018) and bank survival (Berger and Bouwman, 2013).

19 We do not divide the period into crisis and non-crisis periods, because the crisis dates are not clearly defined. For example, the Saving and Loan crisis has been identified in 1988 (Laeven and Valencia, 2013), 1989-1991 (Brownlees and Engle, 2017) or 1990-1992 (Berger and Bouwman, 2013). The 2008 financial crisis has been identified as the period Q3.2007-Q4.2009 (Berger and Bouwman, 2013; and Bouwman et al. 2018), Q3.2007-Q1.2009 (Demirgüç-Kunt et al., 2013) or 2007-2009 (Brownlees and Engle, 2017). More importantly, bank failures frequently happened outside the crisis periods identified by the above studies. As our research focuses on bank stocks, a period of many bank failures seems natural to be viewed as turbulent for the banking sector.

${ }^{20}$ We find that the results of our following analyses are robust when we use June 2007 (or other months in 2007) as the end month. See Section 5.1 for analyses based on alternative definitions of the tranquil period.
} 
in our robustness section. In addition, as COMPUSTAT coverage of banks was relatively poor before 1994 (Bouwman et al., 2018), the analyses for the 1985-1993 period may subject to sample-selection bias. Therefore, our following analyses mainly focus on the tranquil period and the second turbulent period, while results for the 1985-1993 period are provided only for comparison purposes.
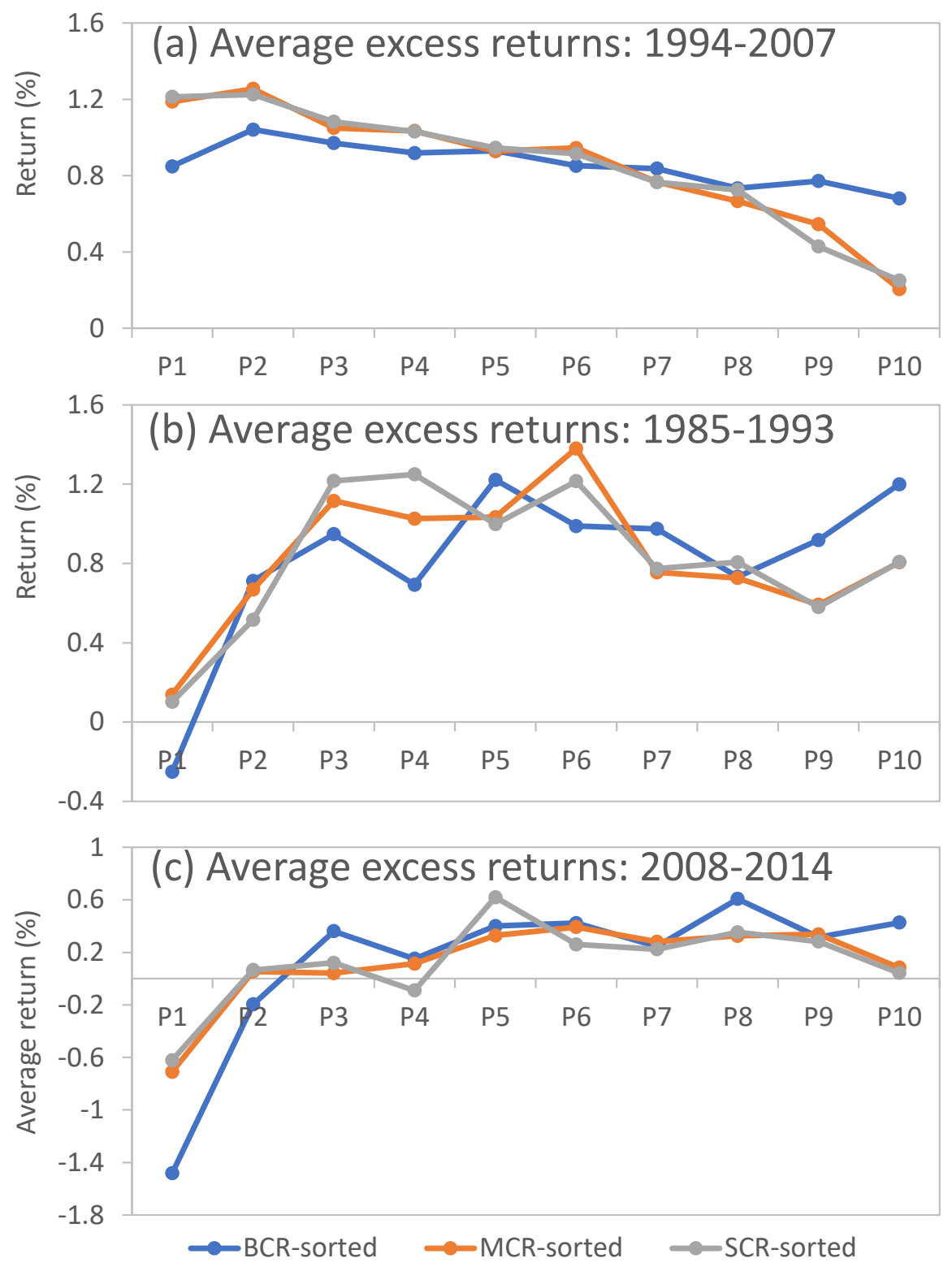

The horizontal axis shows the first to the tenth decile portfolio formed on the basis of banks' BCRs, MCRs or SCRs. The vertical axis shows portfolios' average excess returns during the periods of January 1994-December 2007 (Panel a), January 1985-December 1993 (Panel b) and January 2008-December 2014 (Panel c), where portfolio monthly return is calculated as the equal-weighted one-month-ahead average return across banks in the portfolio minus the risk-free rate.

Figure 6. Portfolio average excess returns during the tranquil and turbulent periods

Figure 6 displays portfolio average excess returns during the tranquil and turbulent periods. 
Panel (a) shows the average excess returns of the decile portfolios during the tranquil period, which clearly suggests a negative relationship between bank capitalization and expected stock returns. For example, portfolio average excess returns nearly monotonically decrease from 0.85\%, $1.19 \%$ and 1.21\% for the first BCR-, MCR- and SCR-sorted decile portfolios to $0.68 \%$, $0.21 \%$ and $0.25 \%$ for the tenth BCR-, MCR- and SCR-sorted decile portfolios, respectively. The differences between returns of the first and the tenth BCR-, MCR- and SCR-sorted decile portfolios are $0.17 \%, 0.98 \%$ and $0.96 \%$ per month, respectively. The difference between the first and the tenth MCR-sorted (SCR-sorted) decile portfolios is economically large, while the difference between the first and the tenth BCR-sorted portfolios is relatively small. In contrast, Panels (b) and (c) of Figure 6 show that portfolio average excess returns tend to increase with bank capitalization during the turbulent periods.

Overall, the above analyses suggest that banks with lower capital ratios have higher expected stock returns during the tranquil period, but this relationship changes during the turbulent period. In the next subsection, we perform Fama-MacBeth regression analysis to further examine the cross-sectional relations between bank capitalization and stock returns over time.

\subsection{Fama-MacBeth regression analysis}

The advantage of portfolio sorting analysis is that we do not need to make any assumptions about the nature of the cross-sectional relationship between bank capitalization and stock returns, but it is difficult to consider the time-varying relationship and to control for other variables that may influence returns. To overcome these drawbacks, we perform Fama-MacBeth regression analysis based on individual bank stocks. The Fama and MacBeth (1973) approach allows us to study the relation over time and to take controls into account.

We perform month-by-month Fama-MacBeth regressions of the cross-section of individual bank stock returns on bank capital ratios controlling for variables like market beta, bank size and book-to-market ratio equity. ${ }^{21}$ The first step is to run the following cross-sectional regressions:

$$
r_{i, t+1}=\delta_{0, t}+\delta_{1, t} C R_{i, t}+\delta_{2, t} \beta_{i, t}+\delta_{3, t} S_{i z e_{i, t}}+\delta_{4, t} B M_{i, t}+\epsilon_{i, t+1}
$$

where $r_{i, t+1}$ is the excess returns of bank stock $i$ in month $t+1$, and $C R_{i, t}$ denotes the BCR, the MCR or the SCR measured in month $t$. $\beta_{i, t}$ indicates bank stock $i$ 's market beta in month

\footnotetext{
21 Empirical evidence shows that size and book-to-market ratio are two important determinants of crosssectional stock returns, in contrast to the market beta (e.g., see Fama and French, 1992; Fu, 2009). Although the results are not reported here, we find that market beta has an insignificant impact on bank stock returns, but size and the book-to-market ratio are significant in most regressions.
} 
$t$, obtained through the one-factor market model regression. ${ }^{22}$ Size is the natural log of a bank's market capitalization and $B M$ is the book-to-market ratio of bank equity. $\delta_{0, t}$ is the intercept, while $\delta_{1, t}, \delta_{2, t}, \delta_{3, t}$ and $\delta_{4, t}$ are respective coefficients. $\epsilon_{i, t+1}$ denotes the forecast errors. The coefficient of interest is $\delta_{1, t}$ which captures the dynamic cross-sectional association of the capital ratios with bank stock returns. The second step is to examine whether the average coefficients are significantly different from zero. To this end, we calculate the time-series averages of the monthly cross-sectional regression coefficients and the standard errors as well as the associated $t$-statistics and $p$-values. The standard errors are adjusted following Newey and West (1987) to address autocorrelation and heteroskedasticity.

Table 2: Coefficients of the capital ratio variables obtained from Fama-MacBeth regressions

This table reports the average coefficients of the three capital ratio variables obtained from monthly FamaMacBeth regressions of individual bank stock returns on bank capital ratios. The columns labeled BCR, MCR and SCR are the coefficients on the BCR, MCR and SCR variables, respectively. Model I indicates the FamaMacBeth regressions for individual bank stock returns on bank capital ratios without controlling for other variables, while Model II controls for banks' market beta, size and BM. For simplicity, we do not report results for the controls. The numbers in parentheses are Newey and West (1987) $t$-statistics that control for autocorrelation and heteroskedasticity. ${ }^{* * *},{ }^{* *}$ and $*$ indicate the significance at the $1 \%, 5 \%$ and $10 \%$ levels, respectively.

\begin{tabular}{ccccccc}
\hline & \multicolumn{2}{c}{ BCR } & \multicolumn{2}{c}{ MCR } & \multicolumn{2}{c}{ SCR } \\
\cline { 2 - 7 } & Model I & Model II & Model I & Model II & Model I & Model II \\
\hline \multirow{2}{*}{$1985-2014$} & $0.06^{*}$ & 0.05 & -0.01 & -0.03 & -0.02 & -0.03 \\
& $(1.78)$ & $(1.53)$ & $(-0.75)$ & $(-1.36)$ & $(-0.80)$ & $(-1.32)$ \\
$1994-2007$ & $-0.03^{*}$ & $-0.04^{* *}$ & $-0.06^{* * *}$ & $-0.05^{* * *}$ & $-0.07^{* * *}$ & $-0.04^{* * *}$ \\
& $(-1.84)$ & $(-2.17)$ & $(-6.11)$ & $(-3.33)$ & $(-6.62)$ & $(-3.37)$ \\
$1985-1993$ & $0.16^{*}$ & 0.13 & 0.03 & -0.05 & 0.03 & -0.05 \\
& $(1.69)$ & $(1.47)$ & $(0.63)$ & $(-0.83)$ & $(0.63)$ & $(-0.74)$ \\
$2008-2014$ & $0.13^{* *}$ & $0.14^{* *}$ & 0.03 & 0.02 & 0.03 & 0.01 \\
& $(2.12)$ & $(2.20)$ & $(0.69)$ & $(0.31)$ & $(0.61)$ & $(0.17)$ \\
\hline
\end{tabular}

To take the potential impact of other variables on the capital ratio variable into account, we first run regressions of individual bank stock returns on bank capital ratios without controlling for other variables (Model I) and then run regressions controlling for beta, size and BM (Model II). ${ }^{23}$ Table 2 reports the results for our Fama-MacBeth regressions. We find that bank capitalization has no significant impact on bank stock returns for the full sample period (1985-2014).

\footnotetext{
${ }^{22}$ The regression specification is

$$
r_{i, d}=\alpha_{i}+\beta_{i} M K T_{d}+\epsilon_{i, d}
$$
}

where $r_{i, d}$ and $M K T_{d}$ are the excess returns of bank stock $i$ and the market index on day $d$, respectively. For each month $t$, we estimate this model using daily return data from the 12-month period covering months $\mathrm{t}-11$ through t to obtain bank stock $i$ 's market beta $\beta$ in month $t$.

${ }^{23}$ We also ran regressions in which we control for only one of the beta, size and BM variables; it turns out that the results are similar to those of Models I and II. 
However, if we focus on the tranquil period (1994-2007), we do find a negative relationship between bank capitalization and bank stock returns, irrespective of the model specification. The coefficients on the MCR and the SCR range from -0.04 to -0.07, being significant at the $1 \%$ level (see Table 2). The BCR has smaller and less significant coefficients than those of the MCR and the SCR, which is probably due to the relatively small variation in banks' BCRs (see Table 1). Overall, the results suggest that bank capitalization has a negative and significant impact on bank stock returns during the tranquil period in which bank failures occurred infrequently. For the turbulent periods, it is difficult to detect a significant relationship between bank capitalization and bank stock returns. Only during the 2008-2014 period, bank capitalization captured by the BCR has a significant and positive impact on bank stock returns. These results confirm our findings from the portfolio sorting analysis that bank capitalization is negatively associated with bank stock returns during the tranquil period, but not during the turbulent periods.

Figure 7 presents monthly cross-sectional coefficients of the BCR, MCR, and SCR variables obtained from the Fama-MacBeth regressions of bank stock returns on the capital ratios controlling for beta, size and BM (see Equation 1). The coefficients of the BCR and the SCR are shifted downwards and upwards with one unit, respectively, so that the difference between the coefficients on the BCR, MCR, and SCR variables can easily be observed.

Figure 7 shows that the coefficients on the BCR, MCR, and SCR variables have very similar dynamics. The coefficients move up and down around zero, but are much more volatile during the 1985-1993 and 2008-2014 periods. This is not surprising, because there were a lot of bank failures in these two periods, which could cause investors to change their beliefs frequently and dramatically (Hoffmann et al., 2013; and Gennaioli et al., 2015). Investors' overreaction would lead to extreme movement of stock prices and hence stock returns as well as the association with capital ratios. In contrast, the coefficients remain relatively stable during the 1994-2007 period when bank failures occurred only occasionally. These different patterns in the coefficients during different periods justify our approach to distinguish between tranquil and turbulent periods when examining the role of bank capitalization in the cross-section of bank stock returns.

To sum up, we uncover a negative relationship between bank capitalization and expected stock returns during the 1994-2007 period. The relationship is particularly significant when bank capitalization is captured by the MCR or the SCR. This relationship does not hold in periods containing many bank failures. Bank capitalization captured by the BCR even had a positive and significant impact on bank stock returns during the period 2008-2014. In the next section, we examine whether the relationship is driven by bank capitalization per se or by the variation in portfolio exposures to systematic risk factors. 


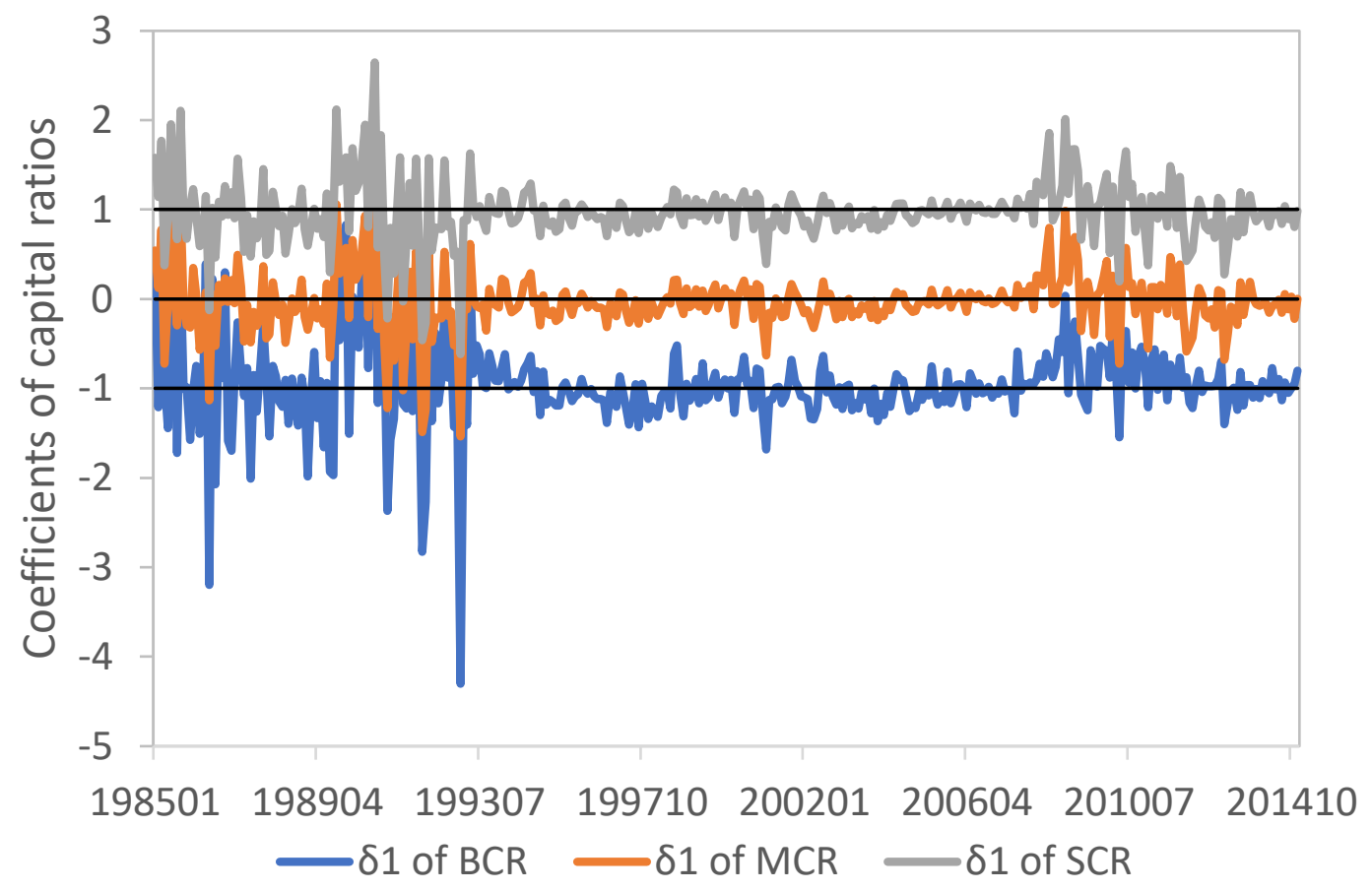

This figure displays monthly cross-sectional coefficients on the BCR, MCR, and SCR variables obtained from the Fama-MacBeth regressions of bank stock returns on the capital ratios controlling for banks' market beta, size and BM (see Equation 1). The coefficients on the BCR and the SCR are shifted downwards and upwards with one unit, respectively, to enable observing the difference among the coefficients on the BCR, MCR, and SCR variables.

Figure 7. Cross-sectional coefficients on the capital ratio variables

\section{Risk-adjusted returns of portfolios formed on bank capital ratios}

The previous section has shown that the BCR has a positive and significant relationship with bank stock excess returns during 2008-2014, but a negative one during 1994-2007. In contrast, the MCR (SCR) has a negative and significant relationship with bank stock excess returns during 1994-2007, but not during 2008-2014. However, modern portfolio theory suggests that only systematic risk matters for stock returns in equilibrium, because idiosyncratic risk can be diversified by holding a portfolio of stocks. This implies that the relationship between capital ratios and bank stock returns may be caused by our capital ratios proxying for systematic risk factors.

Stated alternatively, the cross-sectional relationship with bank stock returns could be driven by the cross-sectional variation in portfolio exposures to systematic risk factors rather than by capital ratios per se. To test this conjecture, we apply the five-factor model of Fama and French 
(2015) (FF5) to estimate risk-adjusted returns and factor loadings of the portfolios formed on the basis of capital ratios, and examine whether there are systematic patterns in the risk-adjusted returns and factor loadings associated with capital ratios. The FF5 model can be written as

$$
\begin{array}{rl}
r_{p, t}=\alpha_{p}+\beta_{M K T} M K T_{t}+\beta_{S M B} S M B_{t}+\beta_{H M L} H & M L_{t} \\
& +\beta_{R M W} R M W_{t}+\beta_{C M A} C M A_{t}+\epsilon_{t},
\end{array}
$$

where $r_{p, t}$ is the portfolio return in excess of the one-month Treasury bill rate; $M K T_{t}$ is the excess return on a broad market index during period $t$; and $S M B$ and $H M L$ are payoffs on the long-short spreads constructed by sorting stocks based on market capitalization and book-tomarket ratio, respectively. $S M B$ and $H M L$ are two factors mimicking the risk related to size and book-to-market ratio, respectively. ${ }^{24} R M W$ indicates the profitability factor, calculated as the returns on a portfolio of long stocks with robust operating profitability and short stocks with weak operating profitability. $C M A$ represents the investment factor, calculated as the returns on a portfolio of long stocks with conservative investment and short stocks with aggressive investment strategies. $^{25}$

Fama and French (2015) find that the FF5 model has better performance in explaining the variation in average stock returns than the three-factor model of Fama and French (1993). We also test the one-factor market model, the three-factor model and the four-factor model of Carhart (1997) for our portfolios and find that they do not outperform the FF5 model. Therefore, our analyses below are only based on the FF5 model.

\subsection{Risk-adjusted returns during the tranquil period}

Table 3 reports regression results of the FF5 model (see Equation 2) for the BCR-, MCRand SCR-sorted portfolios (P1 to P10) and the long-short zero-cost portfolios (P1P10) for the tranquil period from January 1994 to December 2007. We adopt Newey and West (1987) $t$ statistics to correct for autocorrelation and heteroskedasticity. For simplicity, we only report the $t$-statistics for the second last column.

Panel A of Table 3 presents the results for the BCR-sorted portfolios. We do not find significant differences in portfolios' alphas. The difference between alphas of the first and the tenth decile portfolios is insignificant (-0.14\% with a $t$-statistic of -1.09$)$. In addition, we find

\footnotetext{
${ }^{24}$ Barber and Lyon (1997) and Baek and Bilson (2015) provide empirical evidence that size and value effects also exist in financial stock returns. Gandhi and Lustig (2015) uncover a size anomaly in bank stock returns, while Viale et al. (2009) find no evidence for the size and value effects in bank stock returns.

${ }^{25}$ Data on these factors are obtained from Kenneth R. French's website. See http://mba.tuck.dartmouth.edu/ pages/faculty/ken.french/data_library.html.
} 
Table 3: Risk-adjusted returns during 1994-2007

This table summarizes the regression results of the FF5 model (see Equation 2) for the BCR-, MCR- and SCRsorted portfolios (P1 to P10) for the period from January 1994 to December 2007. P1P10 denotes the long-short zero-cost portfolio; it goes long the first decile portfolio (P1) and short for the tenth decile portfolio (P10). The values of $\alpha$ are in percentage. The last column indicates Newey and West (1987) $t$-statistics corresponding to the second last column.

\begin{tabular}{|c|c|c|c|c|c|c|c|c|c|c|c|c|}
\hline Equal-weighted & $\mathrm{P} 1$ & $\mathrm{P} 2$ & P3 & $\mathrm{P} 4$ & $\mathrm{P} 5$ & $\mathrm{P} 6$ & P7 & P8 & P9 & $\mathrm{P} 10$ & $\mathrm{P} 1 \mathrm{P} 10$ & $t$-statistic \\
\hline \multicolumn{13}{|c|}{ Panel A: BCR-sorted portfolios } \\
\hline$\alpha$ & -0.05 & 0.26 & 0.18 & 0.14 & 0.15 & 0.17 & 0.15 & 0.10 & 0.13 & 0.09 & -0.14 & -1.09 \\
\hline $\mathrm{MKT}$ & 0.86 & 0.74 & 0.72 & 0.72 & 0.70 & 0.63 & 0.62 & 0.55 & 0.57 & 0.52 & 0.33 & 5.67 \\
\hline SMB & 0.39 & 0.37 & 0.34 & 0.29 & 0.37 & 0.32 & 0.38 & 0.38 & 0.36 & 0.36 & 0.02 & 0.54 \\
\hline HML & 0.60 & 0.58 & 0.58 & 0.53 & 0.53 & 0.53 & 0.49 & 0.42 & 0.43 & 0.36 & 0.24 & 3.18 \\
\hline RMW & 0.24 & 0.18 & 0.27 & 0.25 & 0.25 & 0.18 & 0.20 & 0.19 & 0.20 & 0.18 & 0.06 & 0.78 \\
\hline CMA & 0.07 & 0.01 & -0.02 & 0.05 & 0.06 & -0.01 & 0.02 & 0.08 & 0.06 & 0.08 & -0.01 & -0.14 \\
\hline Adj. $R^{2}$ & 0.59 & 0.57 & 0.57 & 0.53 & 0.54 & 0.54 & 0.52 & 0.51 & 0.52 & 0.47 & 0.34 & \\
\hline \multicolumn{13}{|c|}{ Panel B: MCR-sorted portfolios } \\
\hline$\alpha$ & 0.38 & 0.57 & 0.38 & 0.29 & 0.22 & 0.20 & 0.05 & -0.04 & -0.18 & -0.55 & 0.93 & 4.71 \\
\hline MKT & 0.81 & 0.64 & 0.59 & 0.65 & 0.63 & 0.67 & 0.63 & 0.64 & 0.65 & 0.71 & 0.10 & 1.57 \\
\hline SMB & 0.39 & 0.38 & 0.37 & 0.42 & 0.36 & 0.35 & 0.38 & 0.32 & 0.30 & 0.29 & 0.11 & 2.57 \\
\hline HML & 0.61 & 0.57 & 0.52 & 0.54 & 0.54 & 0.45 & 0.49 & 0.45 & 0.44 & 0.43 & 0.18 & 1.52 \\
\hline RMW & 0.15 & 0.14 & 0.16 & 0.26 & 0.19 & 0.24 & 0.25 & 0.23 & 0.25 & 0.27 & -0.12 & -1.44 \\
\hline CMA & -0.04 & -0.04 & 0.03 & 0.00 & 0.03 & 0.10 & 0.03 & 0.09 & 0.10 & 0.09 & -0.12 & -0.52 \\
\hline Adj. $R^{2}$ & 0.58 & 0.45 & 0.47 & 0.52 & 0.54 & 0.52 & 0.51 & 0.52 & 0.57 & 0.60 & 0.08 & \\
\hline \multicolumn{13}{|c|}{ Panel C: SCR-sorted portfolios } \\
\hline$\alpha$ & 0.38 & 0.54 & 0.39 & 0.29 & 0.21 & 0.16 & 0.05 & 0.05 & -0.30 & -0.45 & 0.83 & 3.92 \\
\hline MKT & 0.84 & 0.64 & 0.62 & 0.64 & 0.65 & 0.68 & 0.64 & 0.61 & 0.65 & 0.65 & 0.18 & 2.89 \\
\hline SMB & 0.40 & 0.38 & 0.39 & 0.40 & 0.39 & 0.36 & 0.34 & 0.31 & 0.30 & 0.31 & 0.09 & 2.27 \\
\hline HML & 0.60 & 0.60 & 0.55 & 0.53 & 0.55 & 0.45 & 0.46 & 0.43 & 0.45 & 0.43 & 0.16 & 1.23 \\
\hline RMW & 0.16 & 0.12 & 0.18 & 0.24 & 0.22 & 0.26 & 0.26 & 0.22 & 0.24 & 0.23 & -0.07 & -0.74 \\
\hline CMA & -0.01 & -0.05 & 0.00 & 0.04 & 0.03 & 0.09 & 0.06 & 0.07 & 0.11 & 0.05 & -0.07 & -0.27 \\
\hline Adj. $R^{2}$ & 0.59 & 0.45 & 0.50 & 0.50 & 0.55 & 0.53 & 0.54 & 0.50 & 0.56 & 0.59 & 0.12 & \\
\hline
\end{tabular}

that lower-BCR portfolios have higher loadings on the market and value factors, but not on other factors. These results suggest that the BCR proxies for exposures to the market and value factors. After controlling for these factors, the cross-sectional variation in banks' BCRs is not associated with banks' expected stock returns during the 1994-2007 period.

Panel B of Table 3 records the results for the MCR-sorted portfolios. We find significant differences in portfolios' alphas. The difference between alphas of the first and the tenth decile portfolios is economically large and statistically significant $(0.93 \%$ per month with a $t$-statistic 
of 4.71). In addition, we find that lower-MCR portfolios have higher loadings on the market, size and value factors, but not on the profitability and investment factors. However, only the difference of loadings on the size factor is statistically significant, but it is economically small. After controlling for these factors, there is still significant variation in the cross-section of portfolios' alphas. These results suggest that the cross-sectional variation in banks' MCRs is negatively associated with bank stock returns during the 1994-2007 period. This finding is consistent with that of our Fama-MacBeth regression analysis in the previous section.

Panel C of Table 3 presents the results for the SCR-sorted portfolios. These are quite similar to those for the MCR-sorted portfolios. This is not surprising given that banks' MCR and SCR are highly correlated in the cross-section (see Figure 2). The above analyses also indicate the difference between the BCR and the MCR. The MCR represents the market assessment of bank capitalization while the BCR captures bank capitalization based on accounting information.

\subsection{Risk-adjusted returns during the turbulent period}

Section 4.1 suggests that bank capitalization, captured by the MCR or the SCR but not by the BCR, is negatively associated with bank stock returns during the tranquil period 1994-2007. Here we further examine whether bank capitalization has a different association with bank stock returns during the turbulent period 2008-2014 after controlling for several systematic risk factors. As pointed out in Section 2.2, there may be a substantial sample selection bias prior to 1994 due to the significant increase of COMPUSTAT's coverage of banks from 1989 to 1993. Therefore, our analysis below focuses on the 2008-2014 period. ${ }^{26}$

Table 4 reports regression results of the FF5 model (see Equation 2) for the BCR-, MCRand SCR-sorted portfolios (P1 to P10) and the long-short zero-cost portfolios (P1P10) for the turbulent period from January 2008 to December 2014. We adopt the Newey and West (1987) $t$-statistics to correct for autocorrelation and heteroskedasticity. For simplicity, we only report the $t$-statistics for the last second column. We have two main findings which are different from those for the tranquil period.

First, we find that the BCR is positively and significantly associated with bank stock returns during the 2008-2014 period. For instance, the alpha increases from $-1.49 \%$ for the first BCR-sorted portfolio to $0.03 \%$ for the tenth BCR-sorted portfolio. The long-short BCR-sorted portfolio (P1P10) has an alpha of $-1.53 \%(t$-statistic $=-4.24)$ which is statistically significant at the $1 \%$ level. In contrast, the relationship of the MCR or the SCR with bank stock returns

\footnotetext{
${ }^{26}$ To be sure, we also estimate portfolios' risk-adjusted returns during the 1985-1993 period and find similar results as those during the 2008-2014 period. Results are shown in Appendix B.
} 
Table 4: Risk-adjusted returns during 2008-2014

This table summarizes the regression results of the FF5 model (see Equation 2) for the BCR-, MCR- and SCRsorted portfolios (P1 to P10) for the period from January 2008 to December 2014. The values of $\alpha$ are in percentage. P1P10 denotes the long-short zero-cost portfolio; it goes long the first decile portfolio (P1) and short for the tenth decile portfolio (P10). The last column indicates Newey and West (1987) $t$-statistic corresponding to the second last column.

\begin{tabular}{|c|c|c|c|c|c|c|c|c|c|c|c|c|}
\hline Equal-weighted & $\mathrm{P} 1$ & $\mathrm{P} 2$ & P3 & $\mathrm{P} 4$ & $\mathrm{P} 5$ & $\mathrm{P} 6$ & $\mathrm{P} 7$ & P8 & P9 & $\mathrm{P} 10$ & P1P10 & $t$-statistic \\
\hline \multicolumn{13}{|c|}{ Panel A: BCR-sorted portfolios } \\
\hline$\alpha$ & -1.49 & -0.36 & 0.24 & -0.06 & 0.16 & 0.23 & -0.05 & 0.23 & -0.06 & 0.03 & -1.53 & -4.24 \\
\hline MKT & 0.72 & 0.57 & 0.47 & 0.55 & 0.50 & 0.52 & 0.54 & 0.53 & 0.51 & 0.47 & 0.25 & 1.53 \\
\hline SMB & -0.05 & 0.12 & 0.14 & 0.23 & 0.30 & 0.28 & 0.33 & 0.35 & 0.27 & 0.21 & -0.26 & -0.56 \\
\hline HML & 1.07 & 0.73 & 0.64 & 0.58 & 0.65 & 0.79 & 0.87 & 0.75 & 0.54 & 0.35 & 0.72 & 4.65 \\
\hline RMW & -1.03 & -0.55 & -0.61 & -0.67 & -0.56 & -0.62 & -0.28 & -0.32 & -0.46 & -0.23 & -0.80 & -2.35 \\
\hline CMA & -0.46 & -0.24 & -0.09 & 0.01 & 0.10 & -0.04 & -0.19 & 0.17 & 0.53 & 0.40 & -0.86 & -2.09 \\
\hline Adj. $R^{2}$ & 0.58 & 0.62 & 0.69 & 0.73 & 0.77 & 0.74 & 0.75 & 0.75 & 0.75 & 0.77 & 0.26 & \\
\hline \multicolumn{13}{|c|}{ Panel B: MCR-sorted portfolios } \\
\hline$\alpha$ & -0.78 & 0.24 & 0.03 & -0.05 & 0.14 & 0.08 & -0.14 & -0.11 & -0.20 & -0.32 & -0.46 & -1.16 \\
\hline MKT & 0.93 & 0.50 & 0.46 & 0.51 & 0.52 & 0.52 & 0.53 & 0.49 & 0.49 & 0.42 & 0.51 & 3.52 \\
\hline SMB & -0.19 & -0.03 & 0.11 & 0.15 & 0.18 & 0.25 & 0.38 & 0.44 & 0.51 & 0.40 & -0.60 & -1.39 \\
\hline HML & 1.20 & 1.16 & 0.79 & 0.52 & 0.66 & 0.52 & 0.59 & 0.59 & 0.52 & 0.42 & 0.77 & 4.12 \\
\hline RMW & -1.07 & -1.00 & -0.86 & -0.67 & -0.73 & -0.44 & -0.30 & -0.22 & 0.03 & -0.09 & -0.98 & -2.57 \\
\hline CMA & -0.60 & -0.64 & -0.10 & 0.04 & 0.17 & 0.21 & 0.31 & 0.33 & 0.29 & 0.18 & -0.78 & -1.69 \\
\hline Adj. $R^{2}$ & 0.62 & 0.51 & 0.61 & 0.66 & 0.77 & 0.74 & 0.74 & 0.72 & 0.70 & 0.69 & 0.31 & \\
\hline \multicolumn{13}{|c|}{ Panel C: SCR-sorted portfolios } \\
\hline$\alpha$ & -0.67 & 0.24 & 0.05 & -0.35 & 0.44 & -0.04 & -0.23 & -0.05 & -0.19 & -0.32 & -0.35 & -0.94 \\
\hline MKT & 0.92 & 0.49 & 0.51 & 0.59 & 0.46 & 0.52 & 0.55 & 0.46 & 0.48 & 0.40 & 0.52 & 3.87 \\
\hline SMB & -0.18 & 0.07 & 0.06 & 0.24 & 0.21 & 0.25 & 0.37 & 0.42 & 0.40 & 0.36 & -0.55 & -1.35 \\
\hline HML & 1.28 & 1.16 & 0.87 & 0.61 & 0.54 & 0.52 & 0.58 & 0.59 & 0.45 & 0.36 & 0.92 & 5.90 \\
\hline RMW & -1.08 & -1.11 & -0.73 & -0.60 & -0.76 & -0.49 & -0.21 & -0.21 & -0.08 & -0.08 & -0.99 & -2.96 \\
\hline CMA & -0.65 & -0.53 & -0.09 & 0.02 & 0.29 & 0.24 & 0.25 & 0.26 & 0.30 & 0.11 & -0.75 & -1.68 \\
\hline Adj. $R^{2}$ & 0.63 & 0.53 & 0.61 & 0.71 & 0.76 & 0.71 & 0.75 & 0.73 & 0.71 & 0.70 & 0.38 & \\
\hline
\end{tabular}

controlling for the systematic risk factors becomes insignificant during the 2008-2014 period.

Second, we find that the variation in exposures to the value factor (HML) becomes evident for the BCR-, MCR- and SCR-sorted portfolios during the 2008-2014 period. The long-short portfolios (P1P10) also have significantly positive exposures to the value factor. These results are different from those for the 1994-2007 period for which we find that the variation in exposures to the value factor only matters for the variation in returns of the BCR-sorted portfolios. In addition, portfolios of banks with lower capital ratios (either BCRs, MCRs or SCRs) tend to have lower exposures to the size factor (SMB) during the 2008-2014 period, but the variation in 
these exposures is insignificant. These results are different from those for the 1994-2007 period for which we find that the variation in exposures to the size factor matters for the variation in returns of the MCR- and SCR-sorted portfolios.

In conclusion, we find that the BCR is positively and significantly associated with bank stock returns during the 2008-2014 period but not during the 1994-2007 period. In contrast, the MCR and the SCR are negatively and significantly associated with bank stock returns during the 1994-2007 period, but not during the 2008-2014 period. A possible story behind these findings is that during the tranquil period investors rely more on the market assessment of bank capitalization while they turn to focus more on accounting assessment of bank capitalization when a systemic banking crisis occurs. Thus, riskier banks indicated by the MCR or the SCR have to provide higher stock returns during the tranquil period following the risk-return tradeoff. But when bank failures happen frequently and investors prefer to hold high-quality assets, riskier banks indicated by the BCR have lower (or even negative) stock returns, as suggested by the flight-to-quality phenomenon in the US stock market found by Ghysels et al. (2014, 2016) and Kotchoni (2018).

\section{Robustness checks}

This section provides additional analyses to examine the robustness of our findings in Sections 3 and 4. First, we examine in Section 5.1 whether the negative relationship between bank capitalization and bank stock returns during the tranquil period is sensitive to our way to define the period. Second, we address the survivorship bias concern in Section 5.2. Section 5.3 extends the FF5 model to see whether our previous findings remain the same. Section 5.4 explores whether our findings in Section 4 are simply driven by bank size while Section 5.5 examines whether the findings hold for value-weighted portfolios.

\subsection{Alternative definitions of the tranquil and turbulent periods}

In Section 3, we divide the full sample period into a tranquil period (1994-2007) and two turbulent periods (1985-1993 and 2008-2014) according to the frequency of bank failures and find that bank capitalization has a significant impact on bank stock excess returns during the tranquil period. We examine whether this finding holds when these periods are defined differently. As Demirgüç-Kunt et al. (2013) suggest that the subprime mortgage crisis started in the third quarter of 2007, we define the period January 1994-June 2007 as a new tranquil period. Besides, as there were also the LTCM crisis in 1998 and the burst of the dot-com bubble 
between 2000 and 2002, we define the period January 2003-June 2007 as another tranquil period. In addition, we define the second turbulent period as ending in 2012 as the number of bank failures drops after $2011 .^{27}$

Similar to the results shown in Table 2, we run the Fama-MacBeth regressions again but for the newly defined turbulent and tranquil periods, and summarize the results in Table 5. For the tranquil periods, we find that the coefficients of the BCR, the MCR and the SCR are all negative and statistically significant irrespective of the model specification used and the period tested. These results suggest that bank capitalization is negatively and significantly associated with bank stock returns during the two periods. This finding is the same as that for the period 1994-2007 shown in Table 2 and therefore enhances the credibility of our analysis in Section 3.2. Likewise, the results for the 2008-2012 period shown in Table 5 are in line with those for the 2008-2014 period.

Table 5: Cross-sectional relationship between bank capitalization and stock returns

This table reports the average coefficients of the three different capital ratio variables obtained from monthly Fama-MacBeth regressions of individual bank stock returns on bank capital ratios. The columns labeled BCR, MCR and SCR are the coefficients on the BCR, MCR and SCR variables, respectively. Model I indicates the Fama-MacBeth regressions of individual bank stock returns on bank capital ratios without controlling for other variables, while Model II controls for banks' market beta, size and BM. For simplicity, we do not report results for the controls. The numbers in parentheses are Newey and West (1987) $t$-statistics that control for autocorrelation and heteroskedasticity.

\begin{tabular}{ccccccc}
\hline \multirow{2}{*}{ Period } & \multicolumn{2}{c}{ BCR } & \multicolumn{2}{c}{ MCR } & \multicolumn{2}{c}{ SCR } \\
\cline { 2 - 7 } & Model I & Model II & Model I & Model II & Model I & Model II \\
\hline \multirow{2}{*}{$199401-200706$} & -0.04 & -0.04 & -0.07 & -0.05 & -0.07 & -0.05 \\
& $(-1.98)$ & $(-2.33)$ & $(-6.83)$ & $(-3.74)$ & $(-7.38)$ & $(-3.69)$ \\
\multirow{2}{*}{$200301-200706$} & -0.05 & -0.06 & -0.06 & -0.05 & -0.06 & -0.05 \\
& $(-2.76)$ & $(-2.87)$ & $(-2.90)$ & $(-2.43)$ & $(-3.16)$ & $(-2.39)$ \\
$200801-201212$ & 0.2 & 0.2 & 0.07 & 0.06 & 0.07 & 0.06 \\
& $(2.92)$ & $(3.76)$ & $(1.12)$ & $(0.99)$ & $(1.07)$ & $(0.90)$ \\
\hline
\end{tabular}

\subsection{Survivorship bias}

As the actual number of banks and the coverage in our sample vary drastically over time, survivorship bias may be a concern for our analyses. To examine whether survivorship bias affects our results, we identify a sub-sample of banks that exist up to December 2007 and

\footnotetext{
27 The reason to focus on the period 2008-2014 is that until 2014 the number of bank failures in the US was still much higher than in the normal period. For instance, 24 (18) banks failed in 2013 (2014) against 5 annual failures in the quiet period. Nevertheless, as suggested by the referee, we have performed a robustness check shortening the turbulent period until the end of 2012 .
} 
another sub-sample of banks that failed or that were delisted before December 2007. We then examine whether the relationship between bank capitalization and stock returns during the tranquil period 1994-2007 also holds for both sub-samples. For each sub-sample, we again sort banks based on their capital ratios to decile portfolios and apply the FF5 models to adjust for systematic risk. For simplicity, we only report portfolios' risk-adjusted returns during the tranquil period in Table 6. For both sub-samples, we find quite similar results as those for the whole sample, suggesting that survivorship bias is not a concern in our main analyses.

Table 6: Risk-adjusted returns taking into account survivorship bias

This table reports risk-adjusted returns of the BCR-, MCR- and SCR-sorted portfolios obtained through the FF5 model based on a sub-sample of banks existing up to December 2007 (Panel A) and a sub-sample of banks that failed or delisted before December 2007 (Panel B). The last column is Newey and West (1987) $t$-statistic corresponding to the second last column.

\begin{tabular}{ccccccccccccc}
\hline & P1 & P2 & P3 & P4 & P5 & P6 & P7 & P8 & P9 & P10 & P1P10 & $t$-statistic \\
\hline FF5 $\alpha$ & \multicolumn{10}{c}{ Panel A: Banks available up to December 2007 } \\
\hline BCR-sorted & 0.26 & 0.30 & 0.21 & 0.20 & 0.08 & 0.02 & 0.22 & 0.05 & 0.13 & 0.16 & 0.10 & 0.86 \\
MCR-sorted & 0.46 & 0.56 & 0.35 & 0.27 & 0.24 & 0.26 & 0.09 & 0.01 & -0.17 & -0.42 & 0.88 & 5.77 \\
SCR-sorted & 0.45 & 0.49 & 0.38 & 0.34 & 0.27 & 0.15 & 0.10 & 0.05 & -0.27 & -0.34 & 0.79 & 5.14 \\
\hline & \multicolumn{10}{c}{ Panel B: Banks disappeared before December 2007 } \\
\hline BCR-sorted & 0.15 & 0.47 & 0.50 & 0.59 & 0.66 & 0.70 & 0.53 & 0.55 & 0.47 & 0.38 & -0.24 & -1.39 \\
MCR-sorted & 0.58 & 0.91 & 0.79 & 0.53 & 0.64 & 0.63 & 0.73 & 0.22 & 0.23 & -0.25 & 0.83 & 5.13 \\
SCR-sorted & 0.57 & 0.92 & 0.70 & 0.61 & 0.71 & 0.56 & 0.62 & 0.32 & 0.19 & -0.22 & 0.79 & 5.60 \\
\hline
\end{tabular}

\subsection{Alternative risk factor model}

Section 4 finds that the MCR and the SCR have a significant relationship with bank stock returns only during the 1994-2007 period while the BCR has a significant relationship with bank stock returns only during the 2008-2014 period. This section examines whether the relationships are sensitive to the factor model used to obtain risk-adjusted returns and portfolio exposures. As banks manage portfolios of bonds with varying maturities and credit risk, we consider the FF5 model augmented by two bond risk factors suggested by Gandhi and Lustig (2015). This augmented FF5 model can be written as

$$
\begin{aligned}
r_{p, t}=\alpha_{p}+\beta_{M K T} M K T_{t}+\beta_{S M B} S M B_{t}+ & \beta_{H M L} H M L_{t}+\beta_{R M W} R M W_{t} \\
& +\beta_{C M A} C M A_{t}+\beta_{L T G} L T G_{t}+\beta_{C R D} C R D_{t} \epsilon_{t}
\end{aligned}
$$

where LTG and CRD are two bond risk factors, calculated as the excess returns on an index of 10-year bonds issued by the US Treasury and on an index of investment grade corporate bonds, 
respectively.

Table 7 reports risk-adjusted returns of the BCR-, MCR- and SCR-sorted portfolios obtained through the FF5 model augmented by two bond riks factors suggested by Gandhi and Lustig (2015). For simplicity, we only report the intercept of the augmented FF5 model for each portfolio. The last column is Newey and West (1987) $t$-statistic corresponding to the second last column. We still find that the MCR and the SCR have significant relationships with bank stock returns only during the 1994-2007 period while the BCR has a significant relationship with bank stock returns only during the 2008-2014 period. This finding is the same as that found in Section 4.

Table 7: Risk-adjusted returns obtained through the FF5 model augmented by two bond risk factors

This table reports risk-adjusted returns of the BCR-, MCR- and SCR-sorted portfolios obtained through the FF5 model augmented by two bond riks factors suggested by Gandhi and Lustig (2015). For simplicity, we only report the intercept of the augmented FF5 model for each portfolio. The last column is Newey and West (1987) $t$-statistic corresponding to the second last column.

\begin{tabular}{cccccccccccccc}
\hline & P1 & P2 & P3 & P4 & P5 & P6 & P7 & P8 & P9 & P10 & P1P10 & $t$-statistic \\
\hline \multicolumn{10}{c}{ Panel A: Risk-adjusted returns during the } & 1994-2007 period \\
\hline BCR-sorted & -0.12 & 0.20 & 0.12 & 0.07 & 0.09 & 0.11 & 0.11 & 0.05 & 0.07 & 0.03 & -0.15 & -1.09 \\
MCR-sorted & 0.31 & 0.48 & 0.30 & 0.20 & 0.16 & 0.14 & 0.02 & -0.08 & -0.21 & -0.58 & 0.89 & 5.23 \\
SCR-sorted & 0.30 & 0.46 & 0.31 & 0.20 & 0.14 & 0.11 & 0.01 & 0.01 & -0.33 & -0.48 & 0.78 & 4.77 \\
\hline \multicolumn{10}{c}{ Panel B: Risk-adjusted returns during the $2008-2014$ period } \\
\hline BCR-sorted & -1.45 & -0.22 & 0.38 & 0.07 & 0.24 & 0.39 & 0.02 & 0.38 & 0.11 & 0.16 & -1.61 & -3.38 \\
MCR-sorted & -0.77 & 0.43 & 0.14 & 0.04 & 0.24 & 0.24 & -0.02 & 0.08 & -0.10 & -0.19 & -0.57 & -1.37 \\
SCR-sorted & -0.66 & 0.43 & 0.18 & -0.29 & 0.59 & 0.09 & -0.10 & 0.15 & -0.10 & -0.20 & -0.45 & -1.10 \\
\hline
\end{tabular}

\subsection{Controlling for bank size}

Since larger banks tend to have higher MCR and SCR but lower BCR during the tranquil period, and higher BCR, MCR and SCR during the turbulent period (see Figure 4), it is worth to check whether our findings in Section 4 are affected by bank size. Therefore, we revisit our findings in the following two ways.

First, we construct size-capital double sorted bank portfolios following most studies in the field of empirical asset pricing. In each month, we sort banks into quintiles based on their market values in ascending order. Within each quintile, we sort banks into quintiles based on their capital ratios (BCR, MCR and SCR, respectively) in ascending order. Thus, we have 25 
size-capital double sorted bank portfolios. We apply the FF5 model to obtain risk-adjusted returns of these portfolios and calculate the differences between the first and the fifth quintile portfolios within the same size quintiles. For simplicity, we only present the differences in Table 8. For the size-MCR- and size-SCR-sorted portfolios, the difference between the first and the fifth quintile portfolios is significantly positive within all size quintiles during the tranquil period, but insignificant within all size quintiles during the turbulent period. These results are consistent with those shown in Section 4, suggesting that our findings about the association of the MCR and SCR with bank stock returns are not affected by bank size. For the size-BCRsorted portfolios, we find that the difference between the first and the fifth quintile portfolios is insignificant within all size quintiles during the tranquil period. During the turbulent period, the difference is significantly negative only within the first three size quintiles. The results suggest that bank capital captured by the BCR has a positive effect mainly on stock returns of small and medium-sized banks during the turbulent period. ${ }^{28}$ Bank size, only to some extent, matters for the association of the BCR with bank stock returns during the turbulent period.

Table 8: Risk-adjusted returns of portfolios sorted on size and capital ratios

This table records portfolios' risk-adjusted returns (\%) obtained through the FF5 model during the tranquil period (Panel A) and during the turbulent period (Panel B). The portfolios are formed on the basis of bank size and capital ratios. In each month, banks are sorted into quintiles based on their market values in ascending order. Within each quintile, banks are sorted into quintiles based on their capital ratios (BCR, MCR and SCR, respectively) in ascending order. BCR (MCR and SCR) P1P5 indicates the differences between the first and the fifth BCR- (MCR- and SCR-) sorted quintile portfolios within the same size quintiles. The numbers in parentheses are Newey and West (1987) $t$-statistics that correct for autocorrelation and heteroskedasticity.

\begin{tabular}{c|ccc|ccc}
\hline FF5 alphas & \multicolumn{3}{|c|}{ Panel A: 199401-200712 } & \multicolumn{3}{c}{ Panel B: 200801-201412 } \\
\hline Size & BCR P1P5 & MCR P1P5 & SCR P1P5 & BCR P1P5 & MCR P1P5 & SCR P1P5 \\
\hline \multirow{2}{*}{ Small 1 } & -0.03 & 0.64 & 0.69 & -2.68 & -0.31 & -0.29 \\
& $(-0.20)$ & $(2.55)$ & $(3.10)$ & $(-3.97)$ & $(-0.40)$ & $(-0.33)$ \\
\multirow{4}{*}{2} & -0.07 & 0.53 & 0.48 & -1.89 & -0.49 & -0.42 \\
& $(-0.39)$ & $(3.33)$ & $(3.13)$ & $(-1.83)$ & $(-0.53)$ & $(-0.48)$ \\
3 & 0.13 & 0.58 & 0.63 & -0.96 & -0.06 & -0.16 \\
& $(1.07)$ & $(3.72)$ & $(4.46)$ & $(-3.39)$ & $(-0.16)$ & $(-0.42)$ \\
4 & 0.19 & 0.73 & 0.75 & -0.20 & 0.34 & 0.18 \\
& $(1.59)$ & $(3.10)$ & $(3.52)$ & $(-0.98)$ & $(0.98)$ & $(0.54)$ \\
Large 5 & 0.16 & 0.47 & 0.38 & -0.08 & -0.27 & -0.34 \\
& $(1.16)$ & $(3.15)$ & $(2.48)$ & $(-0.21)$ & $(-0.38)$ & $(-0.49)$ \\
\hline
\end{tabular}

\footnotetext{
${ }^{28}$ This is probably because bank capital has a positive effect on the survival of small banks but not on large banks, as found by Berger and Bouwman (2013). Thus, investors perceive the difference in capital ratios of small and medium banks and flight to stocks of safer banks (i.e., higher-BCR banks) during the turbulent period.
} 
Second, Gandhi and Lustig (2015) find that large bank stocks have lower risk-adjusted returns than small bank stocks even though large banks are more levered (i.e., lower capital ratios). They uncover a bank-specific size factor which can help to explain this size effect. One might be concerned that our analyses in Section 4 merely pick up the size effect uncovered by Gandhi and Lustig (2015) instead of a capital effect. To address this concern, we construct the bank-specific size factor following Gandhi and Lustig (2015) ${ }^{29}$ and apply the FF5 model augmented by this size factor to re-estimate risk-adjusted returns of the decile portfolios constructed in Section 4. For simplicity, we only report the results of risk-adjusted returns in Table 9. Again, the results are very similar as those shown in Section 4, suggesting that our analyses in Section 4 remain valid when controlling for Gandhi and Lustig's (2015) size effect.

Table 9: Risk-adjusted returns obtained through the FF5 model augmented by Gandhi and Lustig's (2015) bank-specific size factor

This table reports risk-adjusted returns (\%) of the BCR-, MCR- and SCR-sorted portfolios obtained through the FF5 model augmented by the bank-specific size factor uncovered by Gandhi and Lustig (2015). We construct the bank-specific size factor following Gandhi and Lustig (2015). For simplicity, we only report the intercept of the augmented FF5 model for each portfolio. The last column is Newey and West (1987) $t$-statistic corresponding to the second last column.

\begin{tabular}{cccccccccccccc}
\hline & P1 & P2 & P3 & P4 & P5 & P6 & P7 & P8 & P9 & P10 & P1P10 & $t$-statistic \\
\hline \multicolumn{1}{c}{ Panel A: Risk-adjusted returns during the 1994-2007 period } \\
\hline BCR-sorted & -0.04 & 0.30 & 0.25 & 0.24 & 0.23 & 0.23 & 0.20 & 0.12 & 0.16 & 0.11 & -0.15 & -1.24 \\
MCR-sorted & 0.30 & 0.52 & 0.34 & 0.32 & 0.27 & 0.27 & 0.15 & 0.08 & -0.05 & -0.39 & 0.69 & 3.48 \\
SCR-sorted & 0.31 & 0.50 & 0.37 & 0.34 & 0.26 & 0.23 & 0.14 & 0.16 & -0.19 & -0.31 & 0.62 & 3.23 \\
\hline \multicolumn{10}{c}{ Panel B: Risk-adjusted returns during the $2008-2014$ period } & & \\
\hline BCR-sorted & -1.50 & -0.37 & 0.23 & -0.06 & 0.16 & 0.23 & -0.05 & 0.24 & -0.06 & 0.04 & -1.54 & -5.05 \\
MCR-sorted & -0.79 & 0.23 & 0.03 & -0.06 & 0.14 & 0.08 & -0.14 & -0.11 & -0.20 & -0.31 & -0.48 & -1.37 \\
SCR-sorted & -0.68 & 0.23 & 0.04 & -0.36 & 0.44 & -0.04 & -0.22 & -0.05 & -0.19 & -0.32 & -0.36 & -1.05 \\
\hline
\end{tabular}

\subsection{Results of value-weighted portfolios}

In Sections 3 and 4, we calculate portfolio returns as the equal-weighted average returns across banks in the portfolio so that we can avoid the influence of extremely large banks. The downside of the equal-weighting scheme is that it does not reflect the relative importance of banks in the

\footnotetext{
${ }^{29}$ First, we compute the residuals from the time-series regression of returns of each size-sorted portfolio on the market, size, value and two bond risk factors. See Section 5.3 for the two bond risk factors. Second, we extract the loadings for the second principal component of the residuals computed in the first step for the ten size-sorted portfolios and normalize the loadings to sum to one. Third, we multiply the residuals by the normalized loadings. The results of this multiplication is taken as the bank-specific size factor.
} 
portfolio. Here we examine whether our main findings in Sections 4 remain valid when portfolio returns are calculated in a value-weighting scheme.

We calculate value-weighted returns for each of the BCR-, MCR- and SCR-sorted decile portfolios, and then apply the FF5 model to estimate portfolio risk-adjusted returns and exposures to systematic risk factors. For simplicity, we only report the results of risk-adjusted returns in Table 10. We find similar results as those shown in Section 4 except that the BCR is no longer significantly associated with bank stock returns during the 2008-2014 period. The exception is mainly due to the tenth BCR-sorted portfolio which has an unexpected low alpha of $-0.4 \%$ compared with the other BCR-sorted portfolios during the 2008-2014 period. We do not have data to explore the specific reasons behind this exception, but the other results still support our main finding that the market assessment of bank capitalization matters for bank stock returns during the tranquil period.

Table 10: Risk-adjusted returns of value-weighted portfolios

This table reports risk-adjusted returns of the BCR-, MCR- and SCR-sorted value-weighted portfolios obtained through the FF5 model. For simplicity, we only report the intercept of the FF5 model for each portfolio. The last column is Newey and West (1987) t-statistic corresponding to the second last column.

\begin{tabular}{ccccccccccccc}
\hline Value-weighted & P1 & P2 & P3 & P4 & P5 & P6 & P7 & P8 & P9 & P10 & P1P10 & $t$-statistic \\
\hline FF5 alphas & \multicolumn{1}{c}{ Panel A: Risk-adjusted returns during the 1994-2007 period } \\
\hline BCR-sorted & -0.05 & -0.04 & -0.18 & -0.24 & -0.15 & -0.02 & -0.20 & -0.28 & 0.12 & -0.17 & 0.11 & 0.61 \\
MCR-sorted & 0.07 & 0.18 & -0.05 & 0.24 & 0.20 & 0.12 & -0.16 & 0.05 & -0.29 & -0.31 & 0.38 & 2.22 \\
SCR-sorted & 0.09 & 0.23 & -0.11 & 0.29 & 0.30 & -0.02 & -0.13 & 0.01 & -0.45 & -0.27 & 0.36 & 2.20 \\
\hline \multicolumn{10}{c}{ Panel B: Risk-adjusted returns during the 2008-2014 period } & & \\
\hline BCR-sorted & -0.51 & -0.41 & 0.21 & -0.07 & -0.21 & 0.09 & -0.31 & 0.07 & -0.05 & -0.40 & -0.10 & -0.23 \\
MCR-sorted & -0.91 & -0.77 & 0.24 & 0.77 & -0.20 & 0.09 & 0.25 & -0.03 & -0.05 & -0.26 & -0.65 & -1.60 \\
SCR-sorted & -0.84 & -0.20 & 0.43 & -0.38 & 0.57 & -0.16 & 0.03 & -0.03 & -0.12 & -0.28 & -0.56 & -1.32 \\
\hline
\end{tabular}

\section{Conclusions}

In this paper, we examine the evolution of US bank capitalization and explore its role in the cross section of bank stock returns. We use the BCR, the MCR and the SCR as three proxies for bank capitalization. We find that banks' average BCR rose steadily during the 1985-2014 period while banks' average MCR and average SCR substantially changed along with the banking crises and the changes in financial regulation. Similarly, Flannery and Rangan (2008) also attribute the buildup of bank capital in the 1990s to financial regulatory innovations. While Flannery and Rangan (2008) find that both the BCR and the MCR capture the buildup of bank capital in the 1990s, our results show that they evolve quite differently in the 2000s. Therefore, our 
results point to the necessity to study bank capitalization from different perspectives.

In fact, our Fama-MacBeth regression analysis and portfolio sorting analysis suggest that there is a negative relationship between banks' MCRs (SCRs) and expected excess stock returns during the 1994-2007 period. This negative relationship remains significant in risk-adjusted returns obtained through the five-factor model of Fama and French (2015). In contrast, banks' BCRs are not associated with banks' stock returns. We also find that the BCR proxies for risk exposures to the market and value factors, while the MCR and the SCR proxy for risk exposures to the market and size factors.

In addition, we find that the negative association of bank capitalization with bank stock returns does not hold in periods with frequent bank failures. During the 2008-2014 period, we find that the MCR and the SCR are not associated with bank stock returns, but the BCR is positively associated with bank stock returns. A possible story behind these findings is that during the tranquil period, investors rely more on market assessment of bank capitalization while they turn to focus more on accounting assessment of bank capitalization when a systemic banking crisis occurs. Thus, riskier banks indicated by the MCR or the SCR have to provide higher stock returns during the tranquil period following the traditional risk-return trade-off. But when bank failure happens frequently and investors prefer to hold high-quality assets, riskier banks indicated by the BCR have lower and negative stock returns, as suggested by the flight-to-quality phenomenon found by Ghysels et al. (2014, 2016) and Kotchoni (2018).

Our finding that bank capitalization is negatively and significantly associated with bank stock returns during the 1994-2007 period is contrary to studies which claim that bank capital has no significant effect on bank stock returns before the GFC (Demirgüç-Kunt et al., 2013). We notice that Demirgüç-Kunt et al. (2013) do not examine the effect of bank capitalization over a long period. They only focus on the Q1.2005-Q1.2009 period and their pre-crisis period is restricted to Q1.2006-Q2.2007. Our finding is similar to that of Pelster et al. (2018) who study a large panel of international banks and find that higher Tier 1 capital decreases a bank's stock performance over the 1999-2012 period, while during turbulent times stocks of better capitalized banks perform significantly better. ${ }^{30}$

Two implications can be drawn from our analyses. First, it is important to assess bank

\footnotetext{
${ }^{30}$ Demirgüç-Kunt et al. (2013) and Pelster et al. (2018) estimate panel data models, in which they control for bank-specific and country-specific variables. These control variables are generally only available at quarterly or yearly frequency. Following most previous studies, we use monthly stock returns. Turning to data with a lower frequency would imply that we would lose a lot of information, making it almost impossible to estimate meaningful models. The use of data with different frequency could explain why our results differ from those of Demirgüç-Kunt et al. (2013), but note that our findings are consistent with those of Pelster et al. (2018).
} 
capitalization from different perspectives. Because the book value-based measures are inherently backward-looking and subject to regulatory requirements, they may be unable to provide an accurate and timely assessment about the change of bank capitalization and insolvency risk. Instead, the market-based measures, which take future information into account, could help regulators to timely monitor the situation of the banking sector. Several studies have argued that higher capital requirements may force banks to take more risk in order to achieve target rates of return and therefore do not necessarily reduce the risk in the banking system (e.g., see Kim and Santomero, 1988; Calem and Rob, 1999; Blum, 1999; and Gale, 2010). Second, it is important to differentiate tranquil and turbulent periods when examining the effect of bank capital. The association of bank capitalization with bank stock returns remains stable and significantly negative during the tranquil period, but becomes extremely volatile during the turbulent period. This suggests that bank capital could have different effects in different periods.

\section{Appendix A The stressed capital ratio: Derivation and estima- tion}

This appendix introduces the derivation and estimation of the stressed capital ratio (SCR). Motivated by the approach of conditional capital shortfall (SRISK) of Brownlees and Engle (2017), we derive the market-based capital-to-assets ratio conditional on a severe market decline for banks, i.e. the SCR. A bank's SCR is defined as the expectation on the ratio of the bank's market value of equity relative to its assets conditional on a prolonged market decline:

$$
S C R_{i t}=E_{t}\left(\frac{M E_{i t+h}}{A_{i t+h}} \mid R_{m t+1: t+h}<C\right),
$$

where $M E_{i}$ is the market value of equity of bank $i, A_{i}$ is the value of quasi assets of bank $i$ (i.e., the sum of $M E_{i}$ and book value of debt $\left.D_{i}\right), R_{m}$ is the return on stock market index, and $C$ is a threshold. Equation (A.1) displays the exception at time $t$ on a bank's capital ratio at time $t+h$ if the market return between the period $t+1$ and $t+h$ drops below the threshold $C$.

To estimate the expectation, we derive a reduced form of SCR from its reciprocal as below:

$$
\begin{aligned}
\frac{1}{S C R_{i t}} & =E_{t}\left(\frac{M E_{i t+h}+D_{i t+h}}{M E_{i t+h}} \mid R_{m t+1: t+h}<C\right) \\
& =E_{t}\left[\left(1+\frac{D_{i t+h}}{M E_{i t+h}}\right) \mid R_{m t+1: t+h}<C\right] \\
& =1+E_{t}\left(\frac{D_{i t+h}}{M E_{i t+h}} \mid R_{m t+1: t+h}<C\right) .
\end{aligned}
$$

It is reasonable to expect that a bank's debt remains the same in a short period (e.g. one month), implying that $E_{t}\left(D_{i t+h} \mid R_{m t+1: t+h}<C\right)=D_{i t}$ (Acharya et al., 2012). Therefore, 
Equation (A.2) can be written as

$$
\begin{aligned}
\frac{1}{S C R_{i t}} & =1+\frac{D_{i t}}{E_{t}\left(M E_{i t+h} \mid R_{m t+1: t+h}<C\right)} \\
& =1+\frac{D_{i t}}{M E_{i t} \cdot E_{t}\left[\left(1+R_{i t+1: t+h}\right) \mid R_{m t+1: t+h}<C\right]} \\
& =1+\frac{D_{i t}}{M E_{i t} \cdot\left(1-L R M E S_{i t}\right)} \\
& =\frac{\frac{M E_{i t}+D_{i t}}{M E_{i t}}-L R M E S_{i t}}{1-L R M E S_{i t}} \\
& =\frac{L V G_{i t}-L R M E S_{i t}}{1-L R M E S_{i t}},
\end{aligned}
$$

so that we have

$$
S C R_{i t}=\frac{1-L R M E S_{i t}}{L V G_{i t}-L R M E S_{i t}},
$$

where $L R M E S_{i t}$ denotes the expectation at time $t$ on bank $i$ 's equity return conditional on the market decline between $t+1: t+h$, and $L V G_{i t}$ denotes bank $i$ 's quasi leverage ratio at time t. Equation (A.4) shows that SCR is a decreasing function of the long-run marginal expected shortfall (LRMES) and quasi leverage ratio (LVG). Higher levels of the LRMES and leverage would result in a lower stressed capital ratio, indicating a more vulnerable status of the bank during stressful periods.

To calculate SCR following Equation (A.4), the main task is to estimate LRMES, as LVG can be directly calculated based on available data on the market value of equity and the book value of debt. We estimate LRMES through Monte Carlo simulation based on the GARCH-DCC model of Engle (2002), ${ }^{31}$ because this approach keeps a reasonable balance between prediction accuracy and model complexity (see Brownlees and Engle, 2017). We first simulate a random sample of the $h$-period bank and market's arithmetic returns based on the information available up to the beginning of month $t$ :

$$
\left[\begin{array}{c}
R_{i t+1: t+h}^{s} \\
R_{m t+1: t+h}^{s}
\end{array}\right] \mid \Gamma_{t}, s=1, \cdots, S,
$$

where $S$ is the number of simulations, $t+1: t+h$ indicates $h$ trading days in month $t$, and $\Gamma_{t}$ denotes the information set available at the beginning of month $t$. Then the LRMES for month $t$ is computed as the average of the Monte Carlo simulated returns following Equation (A.6):

$$
L R M E S_{i t}=-\frac{\sum_{s=1}^{s=S} R_{i t+1: t+h}^{s} I\left\{R_{m t+1: t+h}^{s}<C\right\}}{\sum_{s=1}^{s=S} I\left\{R_{m t+1: t+h}^{s}<C\right\}},
$$

where $I\{A\}$ is an indicator function that equals 1 when $A$ holds, and 0 otherwise. We set $h$ equal to 22 trading days corresponding to one month, the threshold $C$ to be negative $10 \%$, and the number of simulations to 10,000 following Brownlees and Engle (2017).

\footnotetext{
${ }^{31}$ Details on the simulation algorithm for LRMES can be found from Brownlees and Engle (2017).
} 
Our capital measure (SCR) is closely related to the SRISK measure of Brownlees and Engle (2017). SRISK estimates the amount of capital that a bank would need in order to meet the regulatory capital requirement when there is market distress. Unlike SRISK, SCR captures what a bank's capital ratio would be when there is market distress. All else equal, SRISK is an increasing function of size so that a larger bank would be considered as systemically riskier according to the SRISK measure. In contrast, a bank's SCR is not explicitly related to its size, see Equation (A.4). All else equal, the SCR measure would suggest that banks of different sizes (but with the same leverage and tail risk captured by LRMES) have the same ability to withstand shocks. The relation between SCR and SRISK can be derived as follows:

$$
S C R_{i t}=\frac{k D_{i t}-S R I S K_{i t}}{D_{i t}-S R I S K_{i t}}
$$

where $k$ is the prudential ratio used in the calculation of SRISK. 


\section{Appendix B Results for the 1985-1993 period}

This appendix presents the results for the five-factor model for the 1985-1993 period. The table has the same set-up as Table 4.

Table B.1: Risk-adjusted returns during 1985-1993

This table summarizes the regression results of the FF5 model (see Equation 2) for the BCR-, MCR- and SCRsorted portfolios (P1 to P10) for the period from January 1985 to December 1993. The values of $\alpha$ are in percentage. P1P10 denotes the long-short zero-cost portfolio; it goes long the first decile portfolio (P1) and short for the tenth decile portfolio (P10). The last column indicates Newey and West (1987) $t$-statistic corresponding to the second last column.

\begin{tabular}{|c|c|c|c|c|c|c|c|c|c|c|c|c|}
\hline Equal-weighted & $\mathrm{P} 1$ & $\mathrm{P} 2$ & P3 & $\mathrm{P} 4$ & $\mathrm{P} 5$ & $\mathrm{P} 6$ & $\mathrm{P} 7$ & $\mathrm{P} 8$ & P9 & $\mathrm{P} 10$ & P1P10 & $t$-statistic \\
\hline & \multicolumn{12}{|c|}{ Panel A: BCR-sorted portfolios } \\
\hline$\alpha$ & -1.49 & -0.40 & -0.07 & -0.33 & 0.27 & 0.02 & 0.24 & -0.15 & 0.19 & 0.61 & -2.10 & -3.46 \\
\hline MKT & 1.51 & 1.37 & 1.26 & 1.10 & 1.13 & 1.03 & 0.94 & 0.86 & 0.86 & 0.81 & 0.70 & 3.95 \\
\hline SMB & 1.19 & 0.91 & 0.66 & 0.73 & 0.56 & 0.73 & 0.62 & 0.41 & 0.47 & 0.58 & 0.61 & 2.10 \\
\hline HML & 2.06 & 1.36 & 1.55 & 1.48 & 1.10 & 1.29 & 0.81 & 1.10 & 0.66 & 0.89 & 1.18 & 4.76 \\
\hline RMW & -0.26 & -0.39 & 0.08 & 0.43 & 0.06 & 0.22 & 0.02 & 0.44 & 0.09 & 0.01 & -0.27 & -0.61 \\
\hline CMA & -0.61 & -0.39 & -1.36 & -1.27 & -0.82 & -0.78 & -0.67 & -0.88 & -0.49 & -0.88 & 0.27 & 0.55 \\
\hline \multirow[t]{2}{*}{ Adj. $R^{2}$} & 0.69 & 0.73 & 0.77 & 0.80 & 0.77 & 0.77 & 0.81 & 0.77 & 0.76 & 0.76 & 0.38 & \\
\hline & \multicolumn{12}{|c|}{ Panel B: MCR-sorted portfolios } \\
\hline$\alpha$ & -0.98 & -0.52 & 0.00 & -0.06 & -0.04 & 0.44 & 0.10 & 0.03 & -0.24 & 0.13 & -1.11 & -2.28 \\
\hline MKT & 1.39 & 1.41 & 1.27 & 1.22 & 1.09 & 1.03 & 0.91 & 0.84 & 0.85 & 0.85 & 0.54 & 3.25 \\
\hline SMB & 0.79 & 1.32 & 0.83 & 0.78 & 0.74 & 0.72 & 0.48 & 0.58 & 0.23 & 0.39 & 0.40 & 1.38 \\
\hline HML & 1.57 & 1.78 & 1.58 & 1.23 & 1.41 & 1.08 & 1.27 & 0.89 & 0.83 & 0.66 & 0.91 & 2.94 \\
\hline RMW & -0.56 & -0.29 & -0.02 & 0.11 & 0.38 & 0.37 & 0.03 & 0.21 & 0.41 & 0.09 & -0.65 & -1.99 \\
\hline CMA & -0.42 & -0.59 & -0.84 & -0.69 & -0.93 & -0.92 & -1.36 & -0.86 & -0.82 & -0.69 & 0.26 & 0.74 \\
\hline \multirow[t]{2}{*}{ Adj. $R^{2}$} & 0.71 & 0.70 & 0.75 & 0.78 & 0.81 & 0.76 & 0.78 & 0.76 & 0.75 & 0.75 & 0.30 & \\
\hline & \multicolumn{12}{|c|}{ Panel C: SCR-sorted portfolios } \\
\hline$\alpha$ & -0.94 & -0.73 & 0.05 & 0.09 & -0.02 & 0.40 & 0.02 & 0.10 & -0.22 & 0.11 & -1.05 & -1.73 \\
\hline MKT & 1.39 & 1.43 & 1.29 & 1.22 & 1.07 & 1.01 & 0.91 & 0.85 & 0.83 & 0.85 & 0.55 & 3.20 \\
\hline $\mathrm{SMB}$ & 0.78 & 1.30 & 0.84 & 0.74 & 0.77 & 0.72 & 0.47 & 0.52 & 0.31 & 0.41 & 0.37 & 1.22 \\
\hline HML & 1.47 & 1.92 & 1.56 & 1.31 & 1.31 & 1.23 & 1.14 & 0.91 & 0.80 & 0.65 & 0.82 & 2.53 \\
\hline RMW & -0.72 & -0.22 & 0.04 & 0.24 & 0.34 & 0.19 & 0.18 & 0.23 & 0.37 & 0.11 & -0.83 & -2.25 \\
\hline CMA & -0.39 & -0.68 & -0.80 & -0.69 & -0.93 & -1.19 & -1.14 & -0.93 & -0.75 & -0.61 & 0.21 & 0.52 \\
\hline Adj. $R^{2}$ & 0.71 & 0.68 & 0.77 & 0.80 & 0.80 & 0.77 & 0.75 & 0.75 & 0.76 & 0.74 & 0.29 & \\
\hline
\end{tabular}




\section{References}

Acharya, V. V., Engle, R., and Pierret, D. (2014). Testing macroprudential stress tests: The risk of regulatory risk weights. Journal of Monetary Economics, 65, 36-53.

Acharya, V. V., Engle, R., and Richardson, M. (2012). Capital shortfall: A new approach to ranking and regulating systemic risks. American Economic Review, 102(3), 59-64.

Acharya, V. V., Philippon, T., Richardson, M., and Roubini, N. (2009). The financial crisis of 2007-2009: Causes and remedies. Financial Markets, Institutions and Instruments, $18(2), 89-137$.

Adrian, T., Crump, R. K., and Vogt, E. (2017). Nonlinearity and flight to safety in the risk-return trade-off for stocks and bonds. Journal of Finance, forthcoming.

Adrian, T., Friedman, E., and Muir, T. (2015). The cost of capital of the financial sector. FRB of NY Staff Report. Retrieved from https://ssrn.com/abstract=2711635

Akhigbe, A., Madura, J., and Marciniak, M. (2012). Bank capital and exposure to the financial crisis. Journal of Economics and Business, 64 (5), 377-392.

Akhigbe, A., and Whyte, A. M. (2004). The Gramm-Leach-Bliley Act of 1999: Risk implications for the financial services industry. Journal of Financial Research, 27(3), 435-446.

Allen, F., Carletti, E., and Marquez, R. (2011). Credit market competition and capital regulation. Review of Financial Studies, 24(4), 983-1018.

Anand, A., Irvine, P., Puckett, A., and Venkataraman, K. (2013). Institutional trading and stock resiliency: Evidence from the 2007-2009 financial crisis. Journal of Financial Economics, $108(3), 773-797$.

Baek, S., and Bilson, J. F. (2015). Size and value risk in financial firms. Journal of Banking and Finance, 55, 295-326.

Baker, M., and Wurgler, J. (2015). Do strict capital requirements raise the cost of capital? Bank regulation, capital structure, and the low-risk anomaly. American Economic Review, 105(5), 315-20.

Barber, B. M., and Lyon, J. D. (1997). Firm size, book-to-market ratio, and security returns: A holdout sample of financial firms. Journal of Finance, 52(2), 875-883.

Berger, A. N. (1995). The relationship between capital and earnings in banking. Journal of Money, Credit and Banking, 27(2), 432-456.

Berger, A. N., and Bouwman, C. H. (2013). How does capital affect bank performance during financial crises? Journal of Financial Economics, 109(1), 146-176.

Bessler, W., and Kurmann, P. (2014). Bank risk factors and changing risk exposures: Capital market evidence before and during the financial crisis. Journal of Financial Stability, 13, $151-166$.

Bessler, W., Kurmann, P., and Nohel, T. (2015). Time-varying systematic and idiosyncratic 
risk exposures of US bank holding companies. Journal of International Financial Markets, Institutions and Money, 35, 45-68.

Billio, M., Getmansky, M., Lo, A. W., and Pelizzon, L. (2012). Econometric measures of connectedness and systemic risk in the finance and insurance sectors. Journal of Financial Economics, 104(3), 535-559.

Blum, J. (1999). Do capital adequacy requirements reduce risks in banking? Journal of Banking and Finance, 23(5), 755-771.

Bouwman, C. H. S., Kim, H., and Shin, S.-O. S. (2018). Bank capital and bank stock performance. Retrieved from https://ssrn.com/abstract=3007364

Brewer III, E., Kaufman, G. G., and Wall, L. D. (2008). Bank capital ratios across countries: Why do they vary? Journal of Financial Services Research, 34(2-3), 177-201.

Brownlees, C., and Engle, R. F. (2017). SRISK: A conditional capital shortfall measure of systemic risk. Review of Financial Studies, 30(1), 48-79.

Caballero, R. J., and Krishnamurthy, A. (2008). Collective risk management in a flight to quality episode. Journal of Finance, 63(5), 2195-2230.

Calem, P., and Rob, R. (1999). The impact of capital-based regulation on bank risk-taking. Journal of Financial Intermediation, 8(4), 317-352.

Campbell, J. Y., Hilscher, J., and Szilagyi, J. (2008). In search of distress risk. Journal of Finance, 63(6), 2899-2939.

Campbell, J. Y., and Viceira, L. M. (2005). The term structure of the risk-return trade-off. Financial Analysts Journal, 61(1), 34-44.

Carhart, M. M. (1997). On persistence in mutual fund performance. Journal of Finance, 52(1), $57-82$.

Carlson, M., Shan, H., and Warusawitharana, M. (2013). Capital ratios and bank lending: A matched bank approach. Journal of Financial Intermediation, 22(4), 663-687.

Chopra, N., Lakonishok, J., and Ritter, J. R. (1992). Measuring abnormal performance: Do stocks overreact? Journal of Financial Economics, 31(2), 235-268.

Curry, T., and Shibut, L. (2000). The cost of the savings and loan crisis: Truth and consequences. FDIC Banking Review, 13, 26-35.

De Bondt, W. F., and Thaler, R. (1985). Does the stock market overreact? Journal of Finance, 40(3), 793-805.

Demirgüç-Kunt, A., Detragiache, E., and Merrouche, O. (2013). Bank capital: Lessons from the financial crisis. Journal of Money, Credit and Banking, 45 (6), 1147-1164.

Demyanyk, Y., and Van Hemert, O. (2009). Understanding the subprime mortgage crisis. Review of Financial Studies, 24 (6), 1848-1880.

Dermine, J. (2015). Basel III leverage ratio requirement and the probability of bank runs. Journal of Banking and Finance, 53, 266-277. 
Diamond, D. W., and Rajan, R. G. (2000). A theory of bank capital. Journal of Finance, $55(6), 2431-2465$.

Dotsey, M., and Kuprianov, A. (1990). Reforming deposit insurance: Lessons from the savings and loan crisis. Economic Review(March), 3-28.

Engle, R. (2002). Dynamic conditional correlation: A simple class of multivariate generalized autoregressive conditional heteroskedasticity models. Journal of Business and Economic Statistics, 20(3), 339-350.

Fama, E. F., and French, K. R. (1992). The cross-section of expected stock returns. Journal of Finance, $47(2), 427-465$.

Fama, E. F., and French, K. R. (1993). Common risk factors in the returns on stocks and bonds. Journal of Financial Economics, 33(1), 3-56.

Fama, E. F., and French, K. R. (2015). A five-factor asset pricing model. Journal of Financial Economics, 116(1), 1-22.

Fama, E. F., and MacBeth, J. D. (1973). Risk, return, and equilibrium: Empirical tests. Journal of Political Economy, 81(3), 607-636.

Fiegenbaum, A., and Thomas, H. (1988). Attitudes toward risk and the risk-return paradox: Prospect theory explanations. Academy of Management Journal, 31(1), 85-106.

Flannery, M., and Rangan, K. P. (2008). What caused the bank capital build-up of the 1990s? Review of Finance, 12(2), 391-429.

$\mathrm{Fu}, \mathrm{F}$. (2009). Idiosyncratic risk and the cross-section of expected stock returns. Journal of Financial Economics, 91(1), 24-37.

Gale, D. (2010). Capital regulation and risk sharing. International Journal of Central Banking, $6(4), 187-204$.

Gandhi, P., and Lustig, H. (2015). Size anomalies in US bank stock returns. Journal of Finance, $70(2), 733-768$.

Gennaioli, N., Shleifer, A., and Vishny, R. (2012). Neglected risks, financial innovation, and financial fragility. Journal of Financial Economics, 104(3), 452-468.

Gennaioli, N., Shleifer, A., and Vishny, R. (2015). Neglected risks: The psychology of financial crises. American Economic Review, 105(5), 310-14.

Ghysels, E., Guérin, P., and Marcellino, M. (2014). Regime switches in the risk-return trade-off. Journal of Empirical Finance, 28, 118-138.

Ghysels, E., Plazzi, A., and Valkanov, R. (2016). The risk-return relationship and financial crises. Retrieved from https://ssrn.com/abstract $=2776702$

Goddard, J., McKillop, D., and Wilson, J. O. (2016). Regulatory change and capital adjustment of US credit unions. Journal of Financial Services Research, 50(1), 29-55.

Gropp, R., and Heider, F. (2010). The determinants of bank capital structure. Review of Finance, $14(4), 587-622$. 
Guerrieri, V., and Shimer, R. (2014). Dynamic adverse selection: A theory of illiquidity, fire sales, and flight to quality. American Economic Review, 104(7), 1875-1908.

Hanson, S. G., Kashyap, A. K., and Stein, J. C. (2011). A macroprudential approach to financial regulation. Journal of Economic Perspectives, 25(1), 3-28.

Herring, R. J. (2018). The evolving complexity of capital regulation. Journal of Financial Services Research, 53(2-3), 183-205.

Hoffmann, A. O., Post, T., and Pennings, J. M. (2013). Individual investor perceptions and behavior during the financial crisis. Journal of Banking and Finance, 37(1), 60-74.

Kho, B.-C., Lee, D., and Stulz, R. M. (2000). US banks, crises, and bailouts: From Mexico to LTCM. American Economic Review, 90(2), 28-31.

Kim, D., and Santomero, A. M. (1988). Risk in banking and capital regulation. Journal of Finance, 43(5), 1219-1233.

Kotchoni, R. (2018). Detecting and measuring nonlinearity. Econometrics, 6(3), 37.

Laeven, L., and Valencia, F. (2013). Systemic banking crises database. IMF Economic Review, $61(2), 225-270$.

Lesle, V., and Avramova, S. (2012). Revisiting risk-weighted assets. IMF Working Papers, $W P / 12 / 90$. Retrieved from https://ssrn. com/abstract $=1654582$

Mariathasan, M., and Merrouche, O. (2014). The manipulation of Basel risk-weights. Journal of Financial Intermediation, 23(3), 300-321.

Mehran, H., and Thakor, A. (2011). Bank capital and value in the cross-section. Review of Financial Studies, 24(4), 1019-1067.

Merrouche, O., and Nier, E. (2010). What caused the global financial crisis? Evidence on the drivers of financial imbalances 1999-2007. IMF Working Paper No. 10/265.

Miles, D., Yang, J., and Marcheggiano, G. (2013). Optimal bank capital. Economic Journal, 123(567), 1-37.

Newey, W. K., and West, K. D. (1987). A simple, positive semi-definite, heteroskedasticity and autocorrelation consistent covariance matrix. Econometrica, 55(3), 703-708.

Noss, J., and Toffano, P. (2016). Estimating the impact of changes in aggregate bank capital requirements on lending and growth during an upswing. Journal of Banking and Finance, 62, 15-27.

Ozoguz, A. (2009). Good times or bad times? Investors' uncertainty and stock returns. Review of Financial Studies, 22(11), 4377-4422.

Pelster, M., Irresberger, F., and Weiß, G. N. (2018). Bank stock performance and bank regulation around the globe. European Journal of Finance, 24(2), 77-113.

Schuermann, T. (2014). Stress testing banks. International Journal of Forecasting, 30(3), $717-728$.

Thakor, A. (2015a). The financial crisis of 2007-2009: Why did it happen and what did we 
learn? Review of Corporate Finance Studies, 4 (2), 155-205.

Thakor, A. (2015b). Lending booms, smart bankers, and financial crises. American Economic Review, 105(5), 305-309.

Van den Heuvel, S. J. (2008). The welfare cost of bank capital requirements. Journal of Monetary Economics, 55(2), 298-320.

Vassalou, M., and Xing, Y. (2004). Default risk in equity returns. Journal of Finance, 59(2), $831-868$.

Veronesi, P. (1999). Stock market overreactions to bad news in good times: A rational expectations equilibrium model. Review of Financial Studies, 12(5), 975-1007.

Viale, A. M., Kolari, J. W., and Fraser, D. R. (2009). Common risk factors in bank stocks. Journal of Banking and Finance, 33(3), 464-472.

Wang, H., Yan, J., and Yu, J. (2017). Reference-dependent preferences and the risk-return trade-off. Journal of Financial Economics, 123(2), 395-414.

Webber, L., and Willison, M. (2011). Systemic capital requirements. Bank of England Working Paper(436). 